\title{
Assisted Reproductive Technology Surveillance - United States, 2015
}

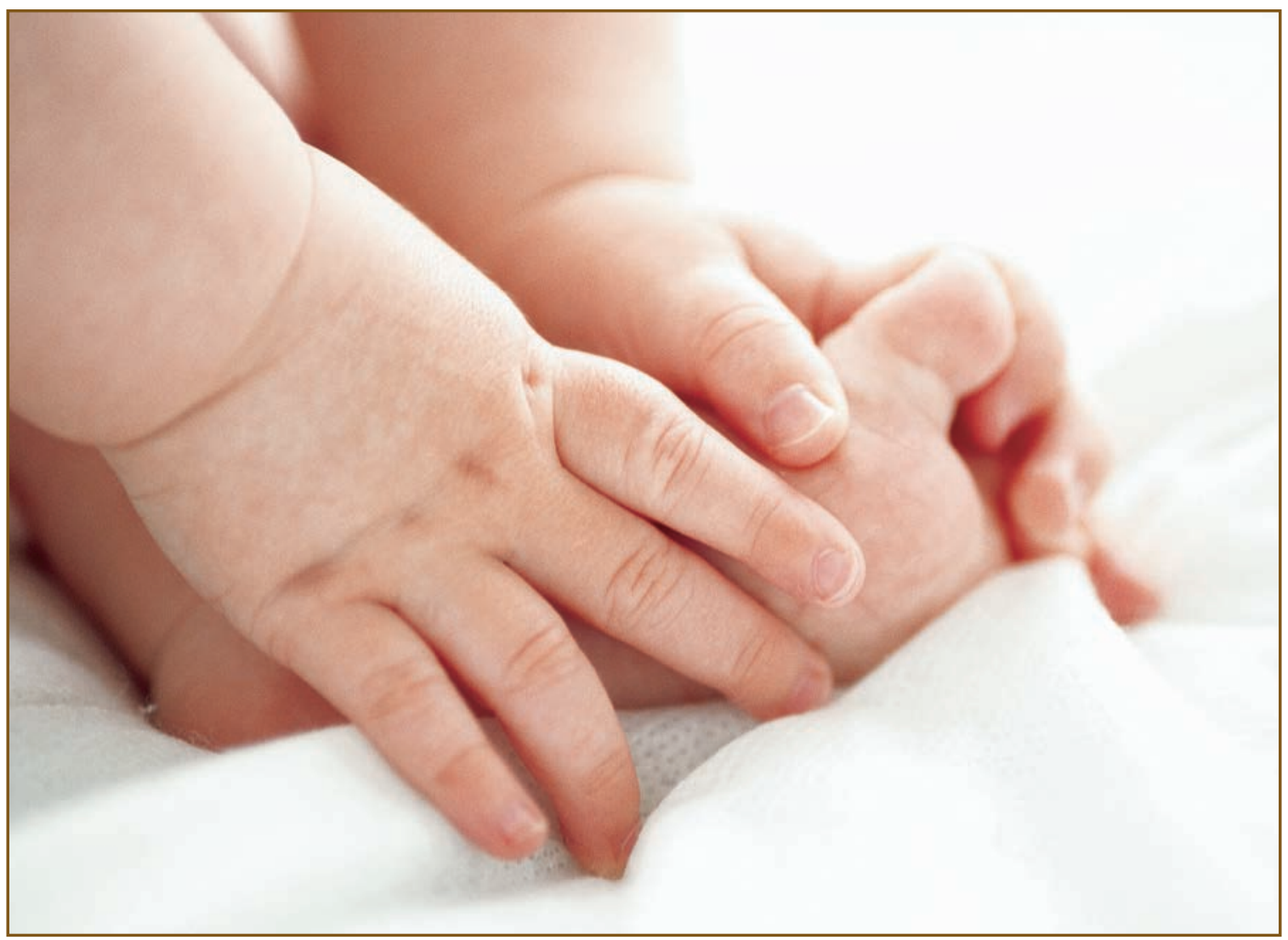




\section{CONTENTS}

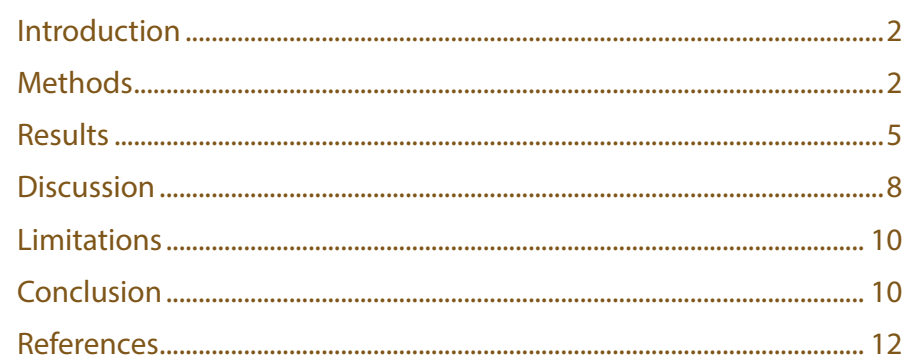

Front cover photo: Photo shows an infant's hands holding its toes.

The MMWR series of publications is published by the Center for Surveillance, Epidemiology, and Laboratory Services, Centers for Disease Control and Prevention (CDC), U.S. Department of Health and Human Services, Atlanta, GA 30329-4027.

Suggested citation: [Author names; first three, then et al., if more than six.] [Title]. MMWR Surveill Summ 2018;67(No. SS-\#):[inclusive page numbers].

\section{Centers for Disease Control and Prevention}

Brenda Fitzgerald, MD, Director

Leslie Dauphin, PhD, Acting Associate Director for Science

Joanne Cono, MD, ScM, Director, Office of Science Quality

Chesley L. Richards, MD, MPH, Deputy Director for Public Health Scientific Services

Michael F. Iademarco, MD, MPH, Director, Center for Surveillance, Epidemiology, and Laboratory Services

\section{MMWR Editorial and Production Staff (Serials)}

Sonja A. Rasmussen, MD, MS, Editor-in-Chief

Charlotte K. Kent, PhD, MPH, Executive Editor Christine G. Casey, MD, Editor

Mary Dott, MD, MPH, Online Editor

Teresa F. Rutledge, Managing Editor

David C. Johnson, Lead Technical Writer-Editor Marella Meadows, Project Editor

Timothy F. Jones, MD, Chairman

Matthew L. Boulton, MD, MPH

Virginia A. Caine, MD

Katherine Lyon Daniel, $\mathrm{PhD}$

Jonathan E. Fielding, MD, MPH, MBA

David W. Fleming, MD

Martha F. Boyd, Lead Visual Information Specialist Maureen A. Leahy, Julia C. Martinroe, Stephen R. Spriggs, Tong Yang, Visual Information Specialists

Quang M. Doan, MBA, Phyllis H. King,

Paul D. Maitland, Terraye M. Starr, Moua Yang, Information Technology Specialists

\section{MMWR Editorial Board}

William E. Halperin, MD, DrPH, MPH

King K. Holmes, MD, PhD

Robin Ikeda, MD, MPH

Rima F. Khabbaz, MD

Phyllis Meadows, PhD, MSN, RN

Jewel Mullen, MD, MPH, MPA
Jeff Niederdeppe, $\mathrm{PhD}$

Patricia Quinlisk, MD, MPH

Patrick L. Remington, MD, MPH Carlos Roig, MS, MA

William L. Roper, MD, MPH

William Schaffner, MD 


\title{
Assisted Reproductive Technology Surveillance - United States, 2015
}

\author{
Saswati Sunderam, $\mathrm{PhD}^{1}$ \\ Dmitry M. Kissin, $\mathrm{MD}^{1}$ \\ Sara B. Crawford, $\mathrm{PhD}^{1}$ \\ Suzanne G. Folger, $\mathrm{PhD}^{1}$ \\ Sheree L. Boulet, $\mathrm{DrPH}^{1}$ \\ Lee Warner, $\mathrm{PhD}^{1}$ \\ Wanda D. Barfield, MD ${ }^{1}$ \\ ${ }^{1}$ Division of Reproductive Health, National Center for Chronic Disease Prevention and Health Promotion, CDC
}

\begin{abstract}
Problem/Condition: Since the first U.S. infant conceived with assisted reproductive technology (ART) was born in 1981, both the use of ART and the number of fertility clinics providing ART services have increased steadily in the United States. ART includes fertility treatments in which eggs or embryos are handled in the laboratory (i.e., in vitro fertilization [IVF] and related procedures). Although the majority of infants conceived through ART are singletons, women who undergo ART procedures are more likely than women who conceive naturally to deliver multiple-birth infants. Multiple births pose substantial risks for both mothers and infants, including obstetric complications, preterm delivery $(<37$ weeks), and low birthweight $(<2,500 \mathrm{~g})$ infants. This report provides state-specific information for the United States (including the District of Columbia and Puerto Rico) on ART procedures performed in 2015 and compares birth outcomes that occurred in 2015 (resulting from ART procedures performed in 2014 and 2015) with outcomes for all infants born in the United States in 2015.
\end{abstract}

Period Covered: 2015.

Description of System: In 1995, CDC began collecting data on ART procedures performed in fertility clinics in the United States as mandated by the Fertility Clinic Success Rate and Certification Act of 1992 (FCSRCA) (Public Law 102-493 [October 24, 1992]). Data are collected through the National ART Surveillance System, a web-based data collection system developed by CDC. This report includes data from 52 reporting areas (the 50 states, the District of Columbia, and Puerto Rico).

Results: In 2015, a total of 182,111 ART procedures (range: 135 in Alaska to 23,198 in California) with the intent to transfer at least one embryo were performed in 464 U.S. fertility clinics and reported to CDC. These procedures resulted in 59,334 live-birth deliveries (range: 55 in Wyoming to 7,802 in California) and 71,152 infants born (range: 68 in Wyoming to 9,176 in California). Nationally, the number of ART procedures performed per 1 million women of reproductive age (15-44 years), a proxy measure of the ART utilization rate, was 2,832. ART use exceeded the national rate in 13 reporting areas (California, Connecticut, Delaware, the District of Columbia, Hawaii, Illinois, Maryland, Massachusetts, New Hampshire, New Jersey, New York, Rhode Island, and Virginia).

Nationally, among ART transfer procedures in patients using fresh embryos from their own eggs, the average number of embryos transferred increased with increasing age of the woman (1.6 among women aged $<35$ years, 1.8 among women aged 35-37 years, and 2.3 among women aged $>37$ years). Among women aged $<35$ years, the national elective single-embryo transfer (eSET) rate was $34.7 \%$ (range: $11.3 \%$ in Puerto Rico to $88.1 \%$ in Delaware).

In 2015, ART contributed to $1.7 \%$ of all infants born in the United States (range: $0.3 \%$ in Puerto Rico to $4.5 \%$ in Massachusetts). ART also contributed to $17.0 \%$ of all multiple-birth infants, $16.8 \%$ of all twin infants, and $22.2 \%$ of all triplets and higher-order infants. The percentage of multiple-birth infants was higher among infants conceived with ART (35.3\%) than among all infants born in the total birth population (3.4\%). Approximately 34.0\% of ART-conceived infants were twins and $1.0 \%$ were triplets and higher-order infants.

Nationally, infants conceived with ART contributed to $5.1 \%$ of all low birthweight infants. Among ART-conceived infants, $25.5 \%$ had low birthweight, compared with $8.1 \%$ among all infants. ART-conceived infants contributed to $5.3 \%$ of all preterm

Corresponding author: Saswati Sunderam, Division of Reproductive Health, National Center for Chronic Disease Prevention and Health Promotion, CDC. Telephone: 770-488-6356; E-mail: msunderam@cdc.gov. (gestational age $<37$ weeks) infants. The percentage of preterm births was higher among infants conceived with ART (31.2\%) than among all infants born in the total birth population $(9.7 \%)$. Among singletons, the percentage of ART-conceived infants who 
had low birthweight was $8.7 \%$ compared with $6.4 \%$ among all infants born. The percentage of ART-conceived infants who were born preterm was $13.4 \%$ among singletons compared with $7.9 \%$ among all infants.

Interpretation: Multiple births from ART contributed to a substantial proportion of all twins, triplets, and higher-order infants born in the United States. For women aged $<35$ years, who are typically considered good candidates for eSET, the national average of 1.6 embryos was transferred per ART procedure. Of the four states (Illinois, Massachusetts, New Jersey, and Rhode Island) with comprehensive mandated health insurance coverage for ART procedures (i.e., coverage for at least four cycles of IVF), three (Illinois, Massachusetts, and New Jersey) had rates of ART use exceeding 1.5 times the national rate. This type of mandated insurance coverage has been associated with greater use of ART and likely accounts for some of the difference in per capita ART use observed among states.

Public Health Action: Twins account for the majority of ART-conceived multiple births. Reducing the number of embryos transferred and increasing use of eSET when clinically appropriate could help reduce multiple births and related adverse health consequences for both mothers and infants. State-based surveillance of ART might be useful for monitoring and evaluating maternal and infant health outcomes of ART in states with high ART use.

\section{Introduction}

Since the birth of the first U.S. infant conceived with assisted reproductive technology (ART) in 1981, use of advanced technologies to overcome infertility has increased, as has the number of fertility clinics providing ART services and procedures in the United States (1). In 1992, Congress passed the Fertility Clinic Success Rate and Certification Act (FCSRCA) (Public Law 102-493 [October 24, 1992]), which requires that all U.S. fertility clinics performing ART procedures report data to CDC annually on every ART procedure performed. CDC initiated data collection in 1995 and in 1997 published the first annual ART Fertility Clinic Success Rates Report (2). Two reports are now produced annually - ART Fertility Clinic Success Rates Report and ART National Summary Report $(1,3)$ - and present several measures of success for ART, including the percentage of ART procedures and transfers that result in pregnancies, live-birth deliveries, singleton live-birth deliveries, and multiple livebirth deliveries.

Although ART helps millions of infertile couples to achieve pregnancy, ART is associated with potential health risks for both mothers and infants. Because multiple embryos are transferred in most ART procedures, ART often results in multiple-gestation pregnancies and multiple births (4-11). Risks to the mother from a multiple birth include higher rate of caesarean delivery, maternal hemorrhage, pregnancy-related hypertension, and gestational diabetes $(12,13)$. Risks to the infant include prematurity, low birthweight, death, and greater risk for birth defects and developmental disability (4-17). Further, singleton infants conceived with ART might have higher risk for low birthweight and prematurity than singletons not conceived with ART (18). However, this higher risk might be associated with singleton births resulting from the transfer of more than one embryo in ART patients who are not good candidates for elective single-embryo transfer (eSET) (19).
This report was compiled on the basis of ART surveillance data reported to CDC's Division of Reproductive Health for procedures performed in 2015. Data on the use of ART are presented for residents of each U.S. state, the District of Columbia, and Puerto Rico; data also are reported on outcomes for infants born in 2015 resulting from ART procedures performed in 2014 and 2015. The report also examines the contribution of ART to select outcomes (i.e., multiple-birth infants, low birthweight infants, and preterm infants) and compares outcomes among ART-conceived infants with outcomes among all infants born in the United States in 2015.

\section{Methods}

\section{National ART Surveillance System}

In 1995, CDC initiated data collection of ART procedures performed in the United States. ART data are obtained from all fertility clinics in the United States through the National ART Surveillance System (NASS), a web-based data collection system developed by CDC (https://www.cdc.gov/art/nass/index.html). Clinics that are members of the Society for Assisted Reproductive Technology (SART) can report their data to NASS through SART. Clinics that are not members of SART can enter their data directly into NASS. All clinics must verify the accuracy of their data that are reported in the clinic table in the annual ART Fertility Clinic Success Rates Report before finalizing submission of their data in NASS. The data then are compiled by Westat and reviewed by both CDC and Westat. A small proportion of clinics (7\%) did not report their data to CDC in 2015 and are listed as nonreporting programs in the 2015 ART Fertility Clinic Success Rates Report, as required by FCSRCA. Because nonreporting clinics tend to be smaller on average than reporting clinics, NASS is estimated to contain information on $98 \%$ of all ART procedures in the United States (1). 
Data collected include patient demographics, medical history, and infertility diagnoses; clinical information pertaining to the ART procedure type; and information regarding resultant pregnancies and births. The data file contains one record per ART procedure (or cycle of treatment) performed. Because ART providers typically do not provide continued prenatal care after a pregnancy is established, information on live births for all procedures is collected by ART clinics. In 2015, this information was obtained either directly from the patient $(73.2 \%)$ or from the patient's obstetric provider $(25.7 \%)$ and reported to NASS. In 2015, approximately $1.1 \%$ of pregnancy outcomes were missing in NASS.

\section{ART Procedures}

ART includes fertility treatments in which eggs or embryos are handled in a laboratory (i.e., in vitro fertilization [IVF], gamete intrafallopian transfer, and zygote intrafallopian transfer). More than $99 \%$ of ART procedures performed are IVF. Because an ART procedure consists of several steps over an interval of approximately 2 weeks, a procedure often is referred to as a cycle of treatment. An ART cycle usually begins with drug-induced ovarian stimulation. If eggs are produced, the cycle progresses to the egg-retrieval stage, which involves surgical removal of the eggs from the ovaries. After the eggs are retrieved, they are combined with sperm in the laboratory during the IVF procedure. For some IVF procedures $(69 \%$ in 2015), a specialized technique (intracytoplasmic sperm injection) is used where a single sperm is injected directly into the egg. If successful fertilization occurs, the most viable embryos (i.e., those that appear morphologically most likely to develop and implant) are selected for transfer back into the uterus. If an embryo implants in the uterus, a clinical pregnancy is diagnosed by the presence of a gestational sac detectable by ultrasound. Most pregnancies will progress to a live-birth delivery, defined as the delivery of one or more live-born infants; however, some result in pregnancy loss (20). ART does not include treatments in which only sperm are handled (i.e., intrauterine insemination) or procedures in which a woman is administered drugs to stimulate egg production without the intention of having eggs retrieved.

ART procedures are classified on the basis of the source of the egg (patient or donor) and the status of the eggs and embryos. Both fresh and thawed embryos can be derived from fresh or frozen eggs of the patient or donor. Patient and donor embryos can be created using sperm from a partner or donor. ART procedures involving fresh eggs and embryos include an eggretrieval stage. ART procedures that use thawed eggs or embryos do not include egg retrieval because the eggs were retrieved during a previous procedure; either the eggs were frozen or the eggs were fertilized and the resultant embryos were frozen until the current procedure. An ART cycle can be discontinued at any step for medical reasons or by patient choice.

\section{Birth Data for United States}

Data on the total number of live-birth and multiple-birth infants in each reporting area in 2015 were obtained from U.S. natality files $(21,22)$. The natality online databases report counts of live births and multiple births occurring within the United States to residents and nonresidents. The data are derived from birth certificates.

\section{Variables and Definitions}

Data on ART and outcomes from ART procedures are presented by patient's residence (i.e., reporting area) at the time of treatment, which might not be the same as the location where the procedure was performed. If information on patient's residence was missing $(0.8 \%$ of procedures performed in 2015 and $1.1 \%$ of live-birth deliveries occurring in 2015), residence was assigned as the location where the procedure was performed. ART procedures performed in the United States among nonresidents are included in NASS data; however, they are excluded from certain calculations for which the exact denominators are not known. To protect confidentiality in the presentation of data in tables, cells with values of 1-4 for ART-conceived infants and with values of $0-9$ for all infants are suppressed, as are data that can be used to derive these cell values; these values are included in the ART totals and in totals for all infants. In some cases as applicable, states are not identified when reporting ranges to protect confidentiality. Because of small numbers, ART data from U.S. territories (with the exception of Puerto Rico) are not included in this report. In addition, estimates derived from cell values $<20$ in the denominator have been suppressed because they are unstable, and estimates could not be calculated when the denominator was zero (e.g., preterm birth among triplets in reporting areas with no triplet births).

This report presents data on all procedures initiated with the intent to transfer at least one embryo with the exception of cycles using fresh embryos created from frozen eggs. The number of ART procedures performed per 1 million women of reproductive age (15-44 years) was calculated, and the resulting rate approximates the proportion of women of reproductive age who used ART in each reporting area. However, this proxy measure of ART use is only an approximation because some women who use ART fall outside the age range of $15-44$ years (approximately 10\% in 2015) and some women might have had more than one procedure during the reporting period. 
A live-birth delivery was defined as the birth of one or more live-born infants. A singleton live-birth delivery was defined as a birth of only one infant who was born live. A multiple livebirth delivery was defined as a birth of two or more infants, at least one of whom was born live. Low birthweight was defined as $<2,500 \mathrm{~g}$ and very low birthweight as $<1,500 \mathrm{~g}$. Gestational age for births among women who did not undergo ART procedures was calculated using a new standard for estimating the gestational age of the newborn. Since 2014, the new measure - obstetric estimate of gestation at delivery (OE) - replaced the measure based on the date of the last normal menstrual period (LMP) (22). Methods of calculating gestational age among women who underwent ART procedures have not changed. For births to women who underwent fresh ART procedures, gestational age was calculated by subtracting the date of egg retrieval from the birth date and adding 14 days. For births to women who underwent frozen embryo cycles or fresh ART procedures for which the date of retrieval was not available, gestational age was calculated by subtracting the date of embryo transfer from the birth date and adding 17 days (to account for an average of 3 days in embryo culture). Preterm delivery was defined as gestational age $<37$ weeks and very preterm delivery as gestational age $<32$ weeks (23).

Elective single-embryo transfer is a procedure in which one embryo, selected from a larger number of available embryos, is placed in the uterus, with extra embryos cryopreserved. Fresh transfer procedures in which only one embryo was transferred but no embryos were cryopreserved are considered single-embryo transfer but not considered eSET. In this report, percentage of eSET procedures and average number of embryos transferred were calculated for patients who used fresh embryos from their own eggs, in which at least one embryo was transferred. The rate of eSET was calculated by dividing the total number of transfer procedures in which only one embryo was transferred and one or more embryos were cryopreserved by the sum of the total number of single-embryo transfer procedures where extra embryos were cryopreserved plus the total number of transfer procedures in which more than one embryo was transferred. Transfer procedures in which only one embryo was transferred but no embryos were cryopreserved were excluded from the calculation of eSET percentage. The average number of embryos transferred by age group ( $<35$ years, 35-37 years, and $>37$ years) was calculated by dividing the total number of embryos transferred by the total number of embryo-transfer procedures performed among that age group.

The contribution of ART to all infants born in a particular reporting area was used as a second measure of ART use. The contribution of ART to adverse birth outcomes (e.g., preterm or low birthweight infant) was calculated by dividing the total number of outcomes among ART-conceived infants by the total number of outcomes among all infants born.

The percentage of infants (ART conceived and all infants) born in a reporting area was calculated by plurality (singleton, multiple, twin, and triplet and higher-order birth) by dividing the number of infants (ART conceived and all infants) in each plurality group by the total number of infants born (ART conceived and all infants). The percentage of infants with low birthweight and preterm delivery was also calculated for each plurality group (singleton, twin, and triplet and higherorder births) for both ART-conceived infants and all infants by dividing the number of low birthweight or preterm infants in each plurality group by the total number of infants in that plurality group.

\section{Content of This Report}

This report provides information on U.S. ART procedures performed in 2015 and compares outcomes for ART-conceived infants born in 2015 (resulting from ART procedures performed in 2014 and 2015) with outcomes for all infants born in 2015 in the United States and Puerto Rico. For each of these reporting areas, data are presented on the number of ART procedures and embryo transfers performed; the resulting number of pregnancies, live-birth deliveries (overall, singleton, and multiple), and live-born infants; and the number of ART procedures in relation to the number of women in the reproductive age group (15-44 years) (24).* Data are also presented on the number of embryo-transfer procedures performed, the average number of embryos transferred, and the percentage of eSET procedures performed among women who used fresh embryos from their own fresh eggs, by age group.

For each reporting area, the proportions of singleton and multiple-birth (including twin and triplet and higher-order multiple) infants resulting from ART are compared with the respective proportions among all infants born in that location in 2015. Infants born in a reporting area during that year include those who were conceived naturally and those resulting from ART and other infertility treatments. To accurately assess the proportion of ART births among overall U.S. births in 2015, ART births were aggregated from two reporting years: 1 ) infants conceived with ART procedures performed in 2014 and born in 2015 (70\% of the live-birth deliveries reported to the ART surveillance system for 2015) and 2) infants conceived with ART procedures performed in 2015 and born in 2015 (30\% of the live-birth deliveries reported to the ART surveillance system for 2015). The report presents the number and percentage of selected adverse perinatal outcomes (low birthweight, very low birthweight, preterm delivery, and very * Data regarding population size were compiled on the basis of July 1, 2015,
estimates from the U.S. Census Bureau. 
preterm delivery) among ART-conceived infants and all infants by plurality, as well as the contribution of ART to these outcomes.

\section{Results \\ Overview of Fertility Clinics}

In 2015, of 499 fertility clinics in the United States that performed ART procedures, a total of 464 (93\%) provided data to CDC, with the majority located in or near major cities (1). The number of fertility clinics performing ART procedures varied by reporting area. The reporting areas with the largest numbers of fertility clinics providing data were California (65), Texas (43), and New York (38) (Figure 1).

\section{Number and Type of ART Procedures}

The number, type, and outcomes of ART procedures performed are provided according to patient's residence for all 52 reporting areas (Table 1). Residency data are missing for approximately $0.8 \%$ of procedures performed and $1.1 \%$ of live-birth deliveries; however, they are included in the totals. In 2015 , approximately $16.3 \%$ of ART procedures were conducted in reporting areas other than the patient's state of residence. Non-U.S. residents accounted for approximately $2.7 \%$ of ART procedures, $3.3 \%$ of ART live-birth deliveries, and $3.0 \%$ of ART-conceived infants born.

In 2015, a total of 231,936 ART procedures were reported to CDC (1). Included in this report are data for 182,111 ART procedures performed in the United States (including Puerto Rico) with the intent to transfer at least one embryo. Excluded are 45,779 egg or embryo-freezing and embryobanking procedures that did not result in an embryo transfer; 4,003 procedures started with the intent to thaw previously frozen eggs, fertilize the eggs, and then transfer the resulting fresh embryos; and 43 procedures that were performed in the territories not included in this report. Of 182,111 procedures performed in the reporting areas, a total of 143,286 (78.7\%) progressed to embryo transfer (Table 1). Of 143,286 ART procedures that progressed to the embryo-transfer stage, $72,870(50.9 \%)$ resulted in a pregnancy and $59,334(41.4 \%)$ in a live-birth delivery. The 59,334 live-birth deliveries included 47,685 singleton live-birth deliveries (80.4\%) and 11,649 multiple live-birth deliveries (19.6\%) and resulted in 71,152 live-born infants (Table 1) (Figure 2).

Six reporting areas with the largest number of ART procedures (California, Illinois, Massachusetts, New Jersey, New York, and Texas) accounted for approximately half (49.5\%) $(90,111$ of 182,111$)$ of all ART procedures, $48.9 \%$ $(70,078$ of 143,286$)$ of all embryo-transfer procedures, $46.8 \%$
FIGURE 1. Location and number* of assisted reproductive technology clinics - United States and Puerto Rico, 2015

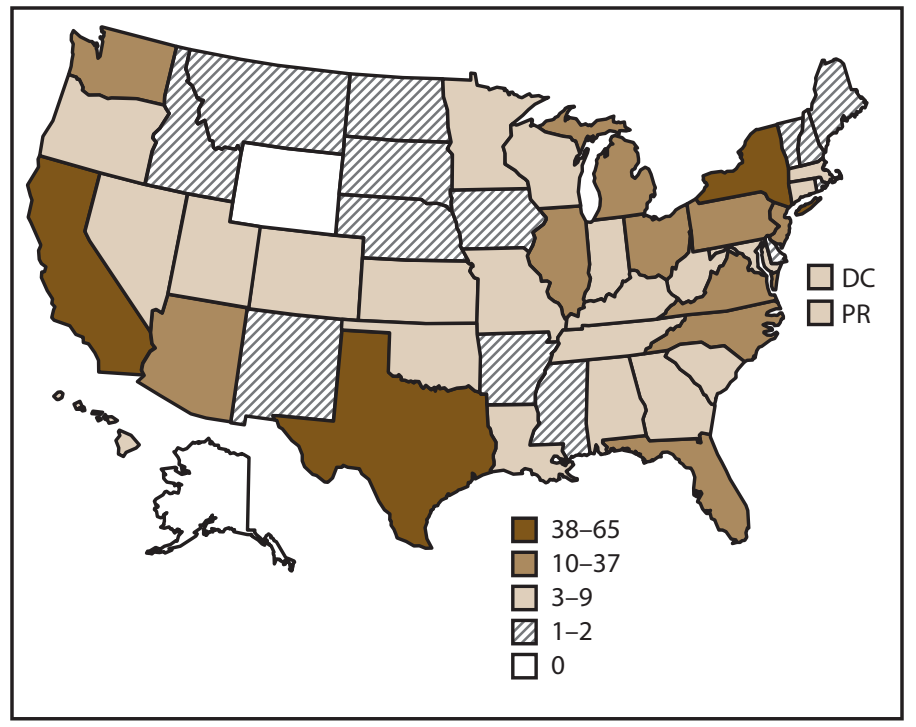

Abbreviations: $\mathrm{DC}=$ District of Columbia; $\mathrm{PR}=$ Puerto Rico.

* In 2015, of the 499 clinics in the United States, 464 (93\%) submitted data.

$(33,294$ of 71,152) of all infants born who were conceived with ART, and 43.4\% (5,054 of 11,649) of all ART-conceived multiple live-birth deliveries in the United States (Table 1). However, these six reporting areas accounted for only $36.6 \%$ of all U.S. births (24).

The number of ART procedures per 1 million women of reproductive age (15-44 years) varied (range: 329 in Puerto Rico to 6,833 in Massachusetts), with an overall national rate of 2,832. Thirteen reporting areas (California, Connecticut, Delaware, Hawaii, Illinois, Maryland, Massachusetts, New Hampshire, New Jersey, New York, Rhode Island, Virginia, and the District of Columbia) had ART use rates higher than the national rate. Of these reporting areas, Massachusetts $(6,833)$ and the District of Columbia $(6,726)$ had rates exceeding twice the national rate, while Connecticut $(4,793)$, Illinois $(4,770)$, Maryland $(5,204)$, New Jersey $(5,581)$, and New York $(5,277)$ had rates exceeding 1.5 times the national rate (Table 1) (Figure 3).

\section{Embryo Transfer and Patient's Age}

The number of embryo-transfer procedures performed, the average number of embryos transferred per procedure, and the percentage of eSET procedures performed among women who used fresh embryos from their own fresh eggs are provided by reporting area and age group (Table 2). Overall, 27,942 embryo-transfer procedures were performed among women aged $<35$ years, 12,943 among women aged $35-37$ years, and 18,429 among women aged $>37$ years. Nationally, on average, 
FIGURE 2. Number of outcomes of assisted reproductive technology procedures, by type of outcome - United States and Puerto Rico, 2015

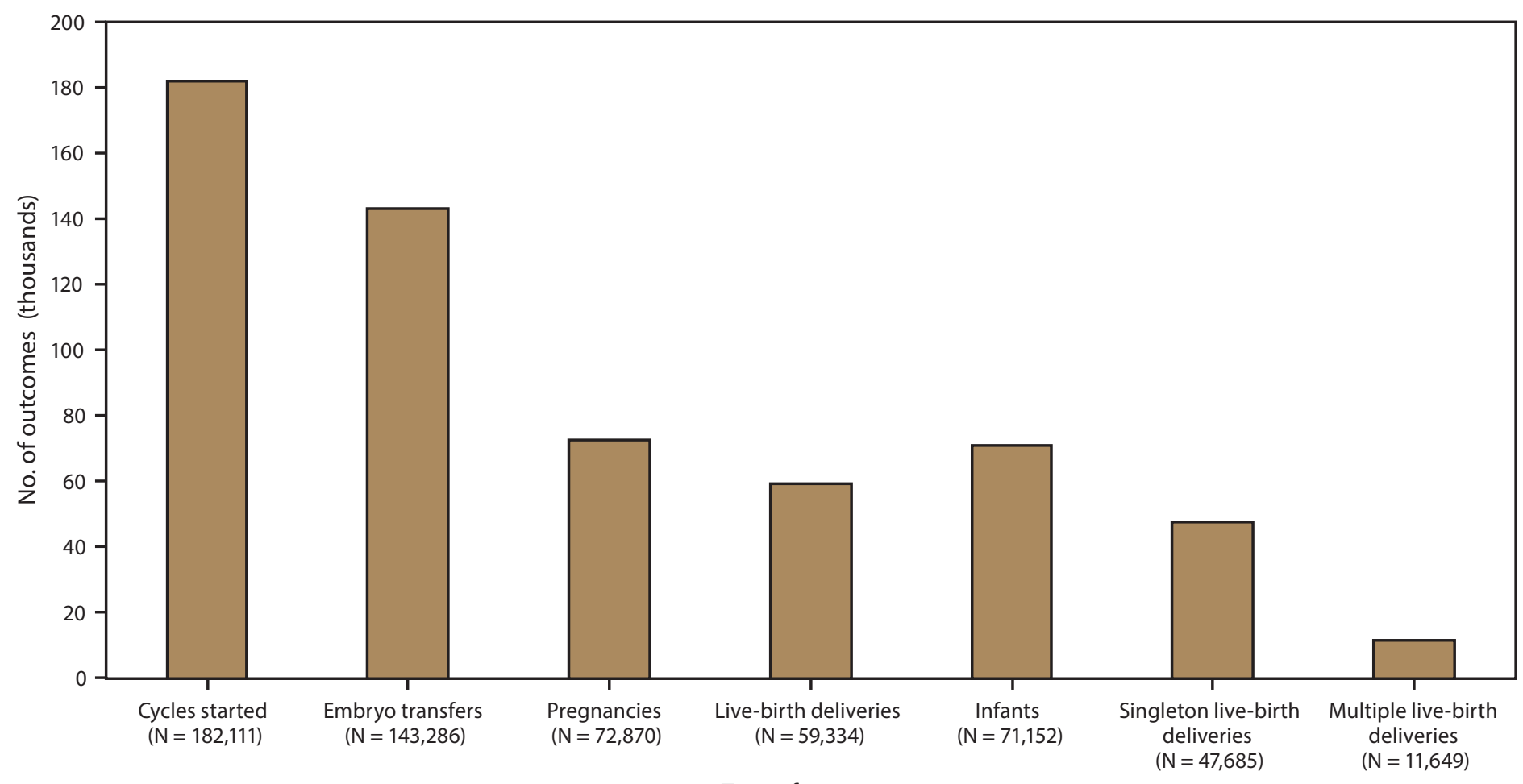

Type of outcome

FIGURE 3. Number of reporting areas, by number of assisted reproductive technology procedures performed among women of reproductive age (15-44 years)* — United States and Puerto Rico, 2015

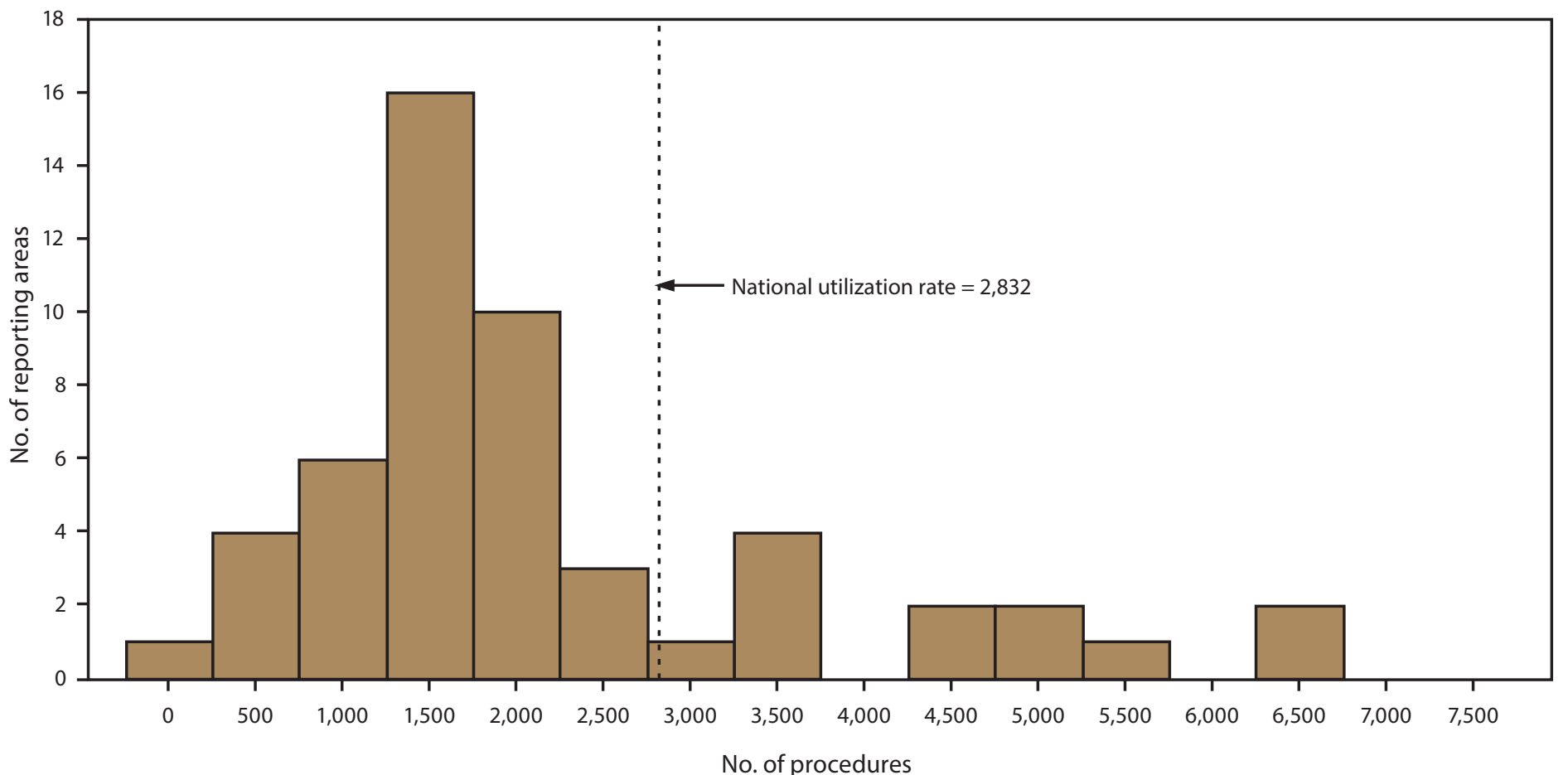

* Per 1 million women aged 15-44 years. 
1.6 embryos were transferred per procedure among women aged $<35$ years (range: 1.1 in Delaware to 2.0 in Puerto Rico), 1.8 among women aged 35-37 years (range: 1.5 in Delaware, Maine, Maryland, and Massachusetts to 2.2 in Puerto Rico), and 2.3 among women aged $>37$ years (range: 1.8 in Arkansas and Nevada to 2.8 in Rhode Island). Nationally, the percentage of eSET was $34.7 \%$ among women aged $<35$ years (range: $11.3 \%$ in Puerto Rico to $88.1 \%$ in Delaware), $20.8 \%$ among women aged 35-37 years (range: $0 \%$ in Puerto Rico to $61.9 \%$ in Delaware), and $2.3 \%$ among women aged $>37$ years (range: $0 \%$ in several reporting areas to $14.3 \%$ in Delaware). Among women aged $<35$ years, eSET percentage exceeded 1.5 times the national percentage in six reporting areas (Delaware, the District of Columbia, Maine, Massachusetts, Maryland, and New Hampshire).

\section{Singleton and Multiple-Birth Infants}

In 2015, among 4,009,654 infants born in the United States and Puerto Rico (21), a total of 66,298 (1.7\%) were conceived with ART procedures performed in 2014 and 2015 (Table 3). California, Texas, and New York had the highest total number of all infants born $(491,748,403,618$, and 237,274, respectively) and ART-conceived infants born $(8,839,5,778$, and 6,435 , respectively). The percentage of ART-conceived infants born among all infants born was highest in Massachusetts (4.5\%), followed by the District of Columbia (3.7\%), Connecticut (3.6\%), and New Jersey (3.5\%).

Nationally, 35.3\% of ART-conceived infants were born in multiple-birth deliveries (range: $18.3 \%$ in Delaware to $57.5 \%$ in Idaho), compared with $3.4 \%$ of all infants (range: $2.3 \%$ in Puerto Rico to $4.7 \%$ in the District of Columbia) (Table 4). ART-conceived twins accounted for approximately $96.1 \%(22,491$ of 23,413$)$ of all ART-conceived infants born in multiple deliveries. ART-conceived multiple-birth infants contributed to $17.0 \%$ of all multiple-birth infants (range: $5.4 \%$ in New Mexico to $44.6 \%$ in Hawaii). Approximately $33.9 \%$ of all ART-conceived infants were twins (range: $16.0 \%$ in Delaware to $53.8 \%$ in Idaho), compared with $3.3 \%$ of all infants (range: $2.3 \%$ in Puerto Rico to $4.6 \%$ in the District of Columbia). ART-conceived twins contributed to $16.8 \%$ of all twins (range: $5.6 \%$ in New Mexico to $43.6 \%$ in Hawaii). Finally, $1.4 \%$ of ART-conceived infants were triplets and higher-order multiples (range: $0 \%$ in several states to $10.3 \%$ in Alaska), compared with $0.1 \%-0.2 \%$ of all infants. ARTconceived triplets and higher-order infants contributed to $22.2 \%$ of all triplets and higher-order infants (range: $0 \%$ in several states to $70.0 \%$ in Hawaii).

\section{Adverse Perinatal Outcomes}

Nationally, ART-conceived infants contributed to approximately $5.1 \%$ of all infants with low birthweight (range: $1.5 \%$ in New Mexico and Puerto Rico to $12.1 \%$ in Connecticut) and $5.0 \%$ of all infants with very low birthweight (range: $0 \%$ in South Dakota and Vermont to $10.9 \%$ in Massachusetts and North Dakota) (Table 5). In four reporting areas (Connecticut, Hawaii, Massachusetts, and New Jersey), $>10 \%$ of all infants with low birthweight born were conceived with ART. In all reporting areas, the percentage of infants with low birthweight and very low birthweight was higher among those conceived with ART than among all infants. Among ART-conceived infants, 25.5\% had low birthweight (range: $13.0 \%$ in Vermont to $48.5 \%$ in Puerto Rico), compared with $8.1 \%$ among all infants (range: $5.7 \%$ in Alaska to $11.4 \%$ in Mississippi). Approximately $4.3 \%$ of ART-conceived infants had very low birthweight (range: $0 \%$ in Vermont and South Dakota to $12.9 \%$ in Puerto Rico), compared with $1.4 \%$ among all infants (range: $0.8 \%$ in Montana to $2.2 \%$ in the District of Columbia).

Nationally, ART contributed to approximately 5.3\% (range: $1.0 \%$ in Puerto Rico to $12.5 \%$ in Massachusetts) and $5.4 \%$ (range: $0 \%$ in Vermont to $11.9 \%$ in Massachusetts) of all infants born preterm and very preterm, respectively (Table 6). In four reporting areas (Connecticut, Hawaii, Massachusetts, and New Jersey), $>10 \%$ of all infants born preterm and very preterm were conceived with ART. As with low birthweight, the percentage of infants who were born preterm and very preterm was higher among ART-conceived infants than among the total birth population. Among ART-conceived infants, 31.2\% were born preterm (range: $11.6 \%$ in Vermont to $45.8 \%$ in Alabama), compared with 9.7\% among all infants (range: 7.3\% in Vermont to $15.0 \%$ in Puerto Rico). Approximately $5.2 \%$ of ART-conceived infants were born very preterm (range: $0 \%$ in Vermont to $14.9 \%$ in Puerto Rico), compared with $1.6 \%$ among all infants (range: $1.0 \%$ in Montana to $2.3 \%$ in Mississippi).

The percentage of ART-conceived infants who had low birthweight was $8.7 \%$ (range: $2.0 \%$ in one state to $22.2 \%$ in Puerto Rico) among singletons, $54.8 \%$ (range: $40.0 \%$ in Vermont to $70.8 \%$ in Puerto Rico) among twins, and $95.9 \%$ (range: $79.2 \%$ in Michigan to $100 \%$ in several reporting areas) among triplets and higher-order multiples; the corresponding percentage among all infants born was $6.4 \%$ (range: $4.6 \%$ in Alaska to $9.4 \%$ in Mississippi) among singletons, $55.2 \%$ (range: $40.5 \%$ in Alaska to $66.1 \%$ in Puerto Rico) among twins, and 95.0\% (range: $76.2 \%$ in Puerto Rico to $100 \%$ in several states) among triplets and higher-order multiples (Table 7 ).

The percentage of ART-conceived infants who were born preterm was $13.4 \%$ among singletons (range: $6.3 \%$ in North Dakota to $20.3 \%$ in South Dakota), 62.4\% among twins 
(range: $30.0 \%$ in Vermont to $83.2 \%$ in Alabama), and $97.7 \%$ among triplets and higher-order infants (range: $87.1 \%$ in California to $100 \%$ in several reporting areas); the corresponding percentage among all infants was $7.9 \%$ for singletons (range: $5.5 \%$ in Vermont to $13.8 \%$ in Puerto Rico), $59.0 \%$ for twins (range: $47.0 \%$ in Alaska to $70.5 \%$ in Louisiana), and 98.6\% for triplets and higher-order infants (range: $90.9 \%$ in Nevada to $100 \%$ in several reporting areas) (Table 8).

\section{Discussion}

\section{Overview}

The use of ART has increased substantially in the United States since the beginning of ART surveillance. In 1996 (the first full year for which ART data were reported to CDC), a total of 20,597 infants were born from 64,036 ART procedures (25). Since then, the number of procedures reported to CDC and the number of infants born from ART procedures have approximately tripled. Several changes can be observed in ART use and outcomes since the preceding reporting year in 2014 (26). The rate of ART use as measured by procedures performed per 1 million women of reproductive age (15-44 years) increased from 2,647 in 2014 to 2,832 in 2015. Among women aged $<35$ years, the average number of embryos transferred remained at 1.6; however, the percentage of eSET increased from 28.5\% to $34.7 \%$. Overall, the percentage of ART-conceived twins decreased from $37.5 \%$ to $33.9 \%$, and the percentage of ARTconceived triplets and higher-order infants decreased from $1.8 \%$ to $1.4 \%$. The contribution of ART-conceived twins to all twins decreased from $18.0 \%$ to $16.8 \%$. The contribution of ART-conceived infants to all triplets and higher-order infants decreased from $26.4 \%$ to $22.2 \%$. However, the contribution of ART to rates of multiple births and poor birth outcomes remained substantial. In 2015, the multiple birth rate was 10 times higher among ART-conceived infants compared with all infants (35.3\% versus 3.4\%), and although infants conceived with ART accounted for approximately $1.7 \%$ of total births in the United States, the proportion of multiple-birth deliveries attributable to ART was $17.0 \%$.

ART-conceived twins accounted for approximately 96.1\% $(22,491$ of 23,413$)$ of all ART-conceived infants born in multiple-birth deliveries. On average, 1.6 embryos were transferred among women aged $<35$ years, even though singleembryo transfers have been associated with better perinatal outcomes among the majority of women in this age group $(27,28)$. The percentage of infants with low birthweight and born preterm was substantially higher among ART-conceived infants (25.5\% and $31.2 \%$, respectively) than among all infants (8.1\% and $9.7 \%$, respectively). Similar to births among the general population, ART-conceived twins and triplets and higher-order infants were more likely than singletons to be born preterm (4.7 times and seven times, respectively).

Comparable data on ART use and embryo transfer practices from 18 European countries indicate that in 2012, ART use as defined by the number of procedures performed per 1 million women of reproductive age was 6,525 ; this was approximately 2.6 times higher than the rate in the United States in 2012 $(29,30)$. Percentages of single-embryo transfers (eSET rates are not reported) varied widely in Europe, and a few countries reported a single-embryo transfer rate of over $50 \%$. Overall, in these 18 reporting countries, approximately $82.1 \%$ of all IVF deliveries were singleton deliveries, compared with $73.5 \%$ in the United States $(29,30)$.

\section{Variations in ART Use by Reporting Area}

ART use (as measured by the number of ART procedures performed per 1 million women of reproductive age) varied widely by reporting area: residents of California, Connecticut, Delaware, Hawaii, Illinois, Maryland, Massachusetts, New Hampshire, New Jersey, New York, Rhode Island, Virginia, and the District of Columbia had higher ART use than the national rate. Although some women who used ART might have been aged $>44$ years, the measure for women aged $15-44$ years is still useful as a proxy indicator of all ART use in each reporting area. Residents of California, Illinois, Massachusetts, New Jersey, New York, and Texas accounted for $46.8 \%$ of all infants conceived with ART. The large number of ART procedures performed in these states is a result of the size of the general population (California and Texas), higher rates of ART use (Massachusetts and New Jersey), or both (New York and Illinois).

The contribution of ART to all infants born varied substantially, even among states with high ART use (range: $1.8 \%$ in California to $4.5 \%$ in Massachusetts). State-level differences might be explained in part by variations in health insurance coverage. Fifteen states (Arkansas, California, Connecticut, Hawaii, Illinois, Louisiana, Maryland, Massachusetts, Montana, New Jersey, New York, Ohio, Rhode Island, Texas, and West Virginia) have passed legislation mandating that private insurers provide coverage for some fertility treatments, although not all mandates require coverage for ART. Mandates from four of these states (Illinois, Massachusetts, New Jersey, and Rhode Island) include comprehensive coverage for at least four cycles of IVF. ${ }^{\dagger}$ Three of the four states with comprehensive

\footnotetext{
$\dagger$ Eight states (Arkansas, Connecticut, Hawaii, Illinois, Maryland, Massachusetts, New Jersey, and Rhode Island) have insurance mandates that cover at least one ART cycle. Seven states (California, Louisiana, Montana, New York, Ohio, Texas, and West Virginia) have insurance mandates that exclude IVF coverage. Information is available at https://resolve.org/what-are-my-options/insurancecoverage/coverage-state/.
} 
mandates (Illinois, Massachusetts, and New Jersey) had rates of ART use that were at least $50 \%$ higher than the national rate. Insurance mandates for infertility treatments have been associated with greater use of ART (31-33). In two states with insurance mandates (Massachusetts and New Jersey), the average number of embryos transferred was less than the national rate and the rate of eSET was higher than the national rate among patients aged $<35$ years.

\section{Elective Single-Embryo Transfer Rates}

Recommendations issued by the American Society of Reproductive Medicine (ASRM) and SART on the number of embryos to transfer have been revised several times to reduce the likelihood of higher-order multiple deliveries (34-38). New guidance issued by ASRM and SART in 2017 is focused on promoting single-embryo transfer and reducing all multiple pregnancies, including twin gestations. Recommendations for single-embryo transfer are now expanded to patients of any age transferring an euploid (i.e., chromosomally normal) embryo, selected with the assistance of preimplantation genetic screening, and for patients aged $<38$ years with any one of these criteria: 1) availability of high-quality embryos for cryopreservation, 2) a history of success with IVF procedures, 3) availability of vitrified blastocyst stage embryos, or 4) undergoing their first frozen embryo transfer (39). Results of an analysis of ART cycles conducted in 2015 suggested that approximately half of ART-related multiple births resulted from the transfer of two fresh embryos among women aged $<35$ years and patients who received donor oocytes; therefore, reducing the number of embryos transferred from two to one among these patients who have a good chance of pregnancy and live birth with single-embryo transfers will lower rates of ART-conceived twins $(40,41)$.

Among women aged $<35$ years, the percentage of eSET procedures was higher $(34.7 \%)$ than among those in older age groups $(20.8 \%$ among women aged $35-37$ years and 2.3\% among women aged $>37$ years) and varied widely among reporting areas (range: 6.7\%-88.1\%). From 2009 to 2015, the national percentage of eSET increased nearly fivefold (from $7.4 \%$ to $34.7 \%$ ) among women aged $<35$ years (26). From 2014 to 2015, the national percentage of eSET among women aged $<35$ years increased from $28.5 \%$ to $34.7 \%$. However, the percentage of eSET is still lower in the United States than in countries that impose restrictions on the number of embryos transferred and provide public funding for ART services (ranging from two to six publicly funded cycles in some countries) (42). The eSET rates might be influenced by factors such as the patient's age and diagnosis, as well as treatment costs that are typically high and often paid out of pocket by the patient (31). In the United States, even where mandated, coverage for infertility treatment can vary in scope, with ART services often excluded or restricted to certain age groups or diagnoses (31). Furthermore, insurance mandates for infertility do not apply to employers that self-insure. In three of the four states with mandatory comprehensive insurance coverage for ART, the eSET percentage among women aged $<35$ years was higher than the national percentage of $34.7 \%$ (70.3\% in Massachusetts, $45.5 \%$ in New Jersey, and $45.5 \%$ in Rhode Island). ART procedures are expensive; out-of-pocket costs per IVF attempt are estimated to be between $\$ 10,000$ and $\$ 15,000$ (32). Insurance mandates for infertility and enhanced coverage for ART might increase the use of eSET because patients might be more willing to transfer fewer embryos when the financial burden of treatment is diminished $(32,43,44)$. In the United States, efforts to increase acceptance and use of eSET still have barriers. Improving adherence to professional guidance on embryo transfer practices along with expanded insurance coverage for ART services might promote greater use of eSET $(40,41,44,45)$.

\section{ART Multiple-Birth Infants}

Singleton live-birth deliveries have lower risks than multiplebirth deliveries for adverse birth outcomes such as prematurity, low birthweight, disability, and death (46-48). To optimize healthy birth outcomes, the transfer of fewer embryos should be encouraged where appropriate, taking into consideration the patient's age and prognosis (27). The percentage of ARTconceived multiple-birth infants in the United States decreased from $53.1 \%$ in 2000 to $35.3 \%$ in 2015 (49). A substantial decrease was noted in both the percentage of ART-conceived triplets and higher-order infants (from $8.9 \%$ in 2000 to $1.4 \%$ in 2015) and the percentage of ART-conceived twins (from $44.2 \%$ in 2000 to $33.9 \%$ in 2015 ).

In the past, the slow decrease in twin-infant birth rates among women who undergo ART procedures was largely attributable to small but gradual increases in eSET rates $(40,41)$. From 2013 to 2014 , a historically large increase $(33.0 \%)$ in the national eSET rate was observed (26). From 2014 to 2015, the increase in the national eSET rate was also substantial (21.8\%) (26). Despite increased eSET use, ARTconceived twins still accounted for approximately one third of all ART-conceived infants in 2015, and on average, 1.6 embryos were transferred among patients aged $<35$ years. High rates of ART-conceived twins might be partially explained by the desire for more than one child among couples experiencing infertility and their perception that the benefits of a multiplegestation pregnancy (compared with no pregnancy) outweigh the risks (50-52). Therefore, understanding the perspective of 
couples undergoing infertility treatments regarding multiplegestation pregnancies and multiple births is important. The use and acceptance of eSET among younger patients with favorable prognoses might be improved through patient education $(53,54)$. Patient education focusing on maternal and perinatal morbidity and mortality, and the economic costs of twin gestations, has been effective in reducing the preference for twins among patients (53-55).

The economic costs of multiple births also underscore the importance of efforts to reduce ART-related multiple births. In 2013, the mean health care cost to patients and insurers was estimated to be $\$ 26,922$ for ART-conceived singleton deliveries, $\$ 115,238$ for ART-conceived twins, and \$434,668 for ART-conceived triplets and higher-order infants (56). Transferring two embryos is associated with a slight increase in overall birth rate but a greater increase in the twin birth rate compared with transferring a single embryo $(27,57)$. However, transferring two embryos sequentially (singleembryo transfer over two sequential procedures) has similar cumulative live-birth rates and lower twin delivery rates than transferring two embryos in a single procedure and might be a cost-effective transfer approach, where estimated costs include ART treatment and pregnancy-and infant-associated medical costs (58-60). Evidence from other countries suggests that insurance coverage for ART combined with restrictions on the number of embryos transferred per cycle can reduce multiple births (42).

\section{ART Low Birthweight Infants and Preterm Births}

The percentage of infants born preterm and very preterm was higher among ART-conceived infants than among infants in the total birth population. Four states (Connecticut, Hawaii, Massachusetts, and New Jersey) that had large numbers of ART procedures performed per 1 million women of reproductive age and a high proportion of ART-conceived infants born in the state also had high contribution of ART $(>10 \%)$ to both categories of low birthweight and preterm births. In the United States, the contribution of ART to preterm births, the majority of which are also infants with low birthweight, is a key concern. Fertility treatments, both ART and controlled ovarian stimulations, contribute substantially to preterm births $(47,61)$. Preterm births are a leading cause of infant mortality and morbidity; preterm infants are at increased risk for death and have more health and developmental problems than full-term infants $(47,62-64)$. The health risks associated with preterm birth have contributed to increased health care costs. In 2005, the societal economic cost associated with all preterm births in the United States was estimated at $\$ 26$ billion annually ( $\$ 51,600$ per infant born preterm) (47). In 2012, the societal economic cost associated with ART-conceived preterm infants in the United States was estimated at approximately $\$ 1.3$ billion (65).

In addition to the known risks for multiple births associated with ART, even singleton infants conceived with ART procedures might be at increased risk for low birthweight and preterm delivery compared with infants born in the general population. However, a study published in 2017 found no significant differences in adverse outcomes among singleton infants conceived after single-embryo transfer among ART patients compared with singletons not conceived with ART, whereas singleton infants conceived after double-embryo transfer were more likely to have adverse perinatal outcomes. Those findings suggested that such differences might be attributable to the transfer of more than one embryo in patients who are not candidates for eSET and might have underlying pathologies (19).

\section{Limitations}

The findings in this report are subject to at least five limitations. First, ART surveillance data were reported for each ART procedure performed rather than for each patient who used ART. As a result, because patients can achieve a successful pregnancy after undergoing multiple procedures, the procedure-specific success rates reported here underestimate the true per-patient success rates. Second, prematurity and low birthweight could be associated with factors contributing to underlying infertility or other maternal factors and not entirely to ART procedures. Third, approximately $7.0 \%$ of fertility clinics that performed ART in 2015 did not report their data to CDC, and these clinics might have had results differing from reporting clinics. Fourth, NASS lacks data on embryo quality, which influences the use of eSET among patients aged $<35$ years with favorable prognoses. Finally, in 2014 the methods for estimating gestational age for women who did not undergo ART changed from LMP measures to OE-based measures. The OE-based preterm birth rates are lower than those estimated with LMP, and therefore comparisons with previous years should be made with caution.

\section{Conclusion}

Since 1995, the number of ART procedures performed in the United States and the number of infants born as a result of these procedures have nearly tripled. With this increasing use, ART-conceived infants represented $1.7 \%$ of infants born in the United States in 2015 and noticeably contributed to the prevalence of low birthweight and preterm deliveries, 
as approximately two fifths of ART-conceived infants were multiple-birth deliveries. Furthermore, among ART-conceived infants, although the percentage of triplets or higher-order infants has decreased since 2000, the percentage of twins has remained high. Because of the higher rates of preterm birth and low birthweight among multiple-birth infants, the impact of ART on poor birth outcomes remains substantial. This report documents the ART use rates and contribution of ART to multiple-birth deliveries, low birthweight, and preterm birth by patient's reporting area of residence. This report also highlights the differences in percentage of low birthweight and prematurity between ART-conceived infants and all infants in the total birth population. These findings allow state health departments to monitor the extent of ART-related adverse perinatal outcomes among singletons, twins, and triplets and higher-order infants in their reporting areas.

Comprehensive insurance coverage of ART can help increase access to fertility treatments (45). Increased use of ART in reporting areas with insurance mandates also can result in higher absolute numbers of ART-conceived multiple-birth deliveries. The findings in this report indicate that ART use was higher than the national rate in all four states with statewide-mandated comprehensive insurance coverage. Three of these four states (Illinois, Massachusetts, and New Jersey) had use rates exceeding 1.5 times the national rate and two (Massachusetts and New Jersey) had a percentage of multiple births that was lower than the national percentage. Further, in both Massachusetts and New Jersey, among patients aged $<35$ years, the average number of embryos transferred was less than the national rate and the rate of eSET was higher than the national rate. More research is needed to ascertain the influence of state health insurance mandates on ART use, embryo transfer practices, infant outcomes, and economic and out-of-pocket patient costs of multiple births $(28,34,40,41)$. Addressing the risk for multiple-birth deliveries also requires understanding the perspectives of couples undergoing infertility treatments who might view a multiple birth, especially twins, as an acceptable or desired outcome or who might lack awareness of the increased risks associated with multiple births to mothers and infants. Although the majority of clinicians acknowledge that the birth of a healthy singleton is the best outcome of ART, they might be sensitive to patient perspectives and experiences with infertility $(34,35)$. Clinicians need to be aware of ongoing efforts and newly published guidance (39) to limit the number of embryos transferred to reduce the rate of multiple births, particularly twins. The wider implementation of eSET, when clinically appropriate, should be encouraged as a mechanism of promoting singleton infant births among ART pregnancies $(27,39,41)$.

In 2014, CDC outlined a public health strategy for the detection, prevention, and management of infertility, including improving ART practice and outcomes, through coordinated efforts of government and nongovernment organizations. This national effort involves federal, state, and local agencies; the scientific community; health care professionals; insurance providers; employers; industry; nonprofit organizations; and organizations representing persons coping with infertility (66). Of public health importance is the role that infertility treatment has on adverse birth outcomes, primarily because of higher rates of multiple births. ART only partially explains the overall prevalence of these adverse outcomes in the United States. Other factors influencing multiple births include maternal age at conception and the use of non-ART fertility treatments $(47,61,67)$. During 1980-2009, the older age of women giving birth accounted for a substantial increase in twins, thought to be attributed to the increased likelihood of an embryo splitting as a woman ages (67). The risk for multiple gestations associated with non-ART fertility treatments (i.e., controlled ovarian stimulation and ovulation induction coupled with timed intercourse or intrauterine insemination) is less well documented than that associated with ART procedures because clinics are only required to report data on ART use. However, research suggests that non-ART fertility treatments might contribute a larger percentage of multiple births than ART fertility treatments. In 2011, approximately $19 \%$ of twin births and $45 \%$ of triplet or higher-order births in the United States were attributable to non-IVF fertility treatments whereas $17 \%$ of twin births and $32 \%$ of triplet or higher-order births were attributable to IVF fertility treatments (61). Further efforts are needed to monitor the use of non-ART fertility treatments and their role in multiple-birth deliveries, particularly because the ability to control the occurrence of a multiple birth is more challenging when using non-ART fertility treatments $(47,61)$. Multiple gestations resulting from non-ART fertility treatments also contribute to preterm births $(47,61)$. Additional research is needed to identify the causes and consequences of preterm births that occur specifically as a result of infertility treatments and support further guidance to reduce the number of multiple gestations $(47,61)$. However, studies have demonstrated that singleton infants conceived with ovulation stimulation are more likely than naturally conceived infants to be small for gestational age (68). CDC is monitoring the prevalence of non-ART fertility treatment use and resultant outcomes among women who had live births in several states participating in the Pregnancy Risk Assessment Monitoring System (69).

As of January 2016, all states have adopted the 2003 revision of the birth certificate that includes information on whether the pregnancy resulted from the use of infertility treatment; 47 states and the District of Columbia differentiate between the use of ART and non-ART treatments. CDC also is working 
to improve state-based surveillance of ART, infertility, and other birth-related matters by linking data from NASS to data collected by states (i.e., birth certificate, infant death, hospital discharge, and birth defect registry information). This initiative, the States Monitoring Assisted Reproductive Technology (SMART) Collaborative (https://www.cdc.gov/ art/smart/index.html), has been determined to be feasible and useful for monitoring long-term outcomes of ART in selected states $(70,71)$. CDC will continue to provide updates of ART use in the United States as data become available.

\section{References}

1. CDC; American Society for Reproductive Medicine; Society for Assisted Reproductive Technology. 2015 assisted reproductive technology fertility clinic success rates report. Atlanta, GA: US Department of Health and Human Services; 2017.

2. CDC; American Society for Reproductive Medicine; Society for Assisted Reproductive Technology; RESOLVE. 1995 assisted reproductive technology success rates. Atlanta, GA: US Department of Health and Human Services; 1997.

3. CDC; American Society for Reproductive Medicine; Society for Assisted Reproductive Technology. 2013 assisted reproductive technology national summary report. Atlanta, GA: US Department of Health and Human Services; 2015.

4. Schieve LA, Peterson HB, Meikle SF, et al. Live-birth rates and multiplebirth risk using in vitro fertilization. JAMA 1999;282:1832-8. https:// doi.org/10.1001/jama.282.19.1832

5. Schieve LA, Meikle SF, Peterson HB, Jeng G, Burnett NM, Wilcox LS. Does assisted hatching pose a risk for monozygotic twinning in pregnancies conceived through in vitro fertilization? Fertil Steril 2000;74:288-94. https://doi.org/10.1016/S0015-0282(00)00602-6

6. Reynolds MA, Schieve LA, Martin JA, Jeng G, Macaluso M. Trends in multiple births conceived using assisted reproductive technology, United States, 1997-2000. Pediatrics 2003;111:1159-62.

7. Reynolds MA, Schieve LA, Jeng G, Peterson HB, Wilcox LS. Risk of multiple birth associated with in vitro fertilization using donor eggs. Am J Epidemiol 2001;154:1043-50. https://doi.org/10.1093/ aje/154.11.1043

8. Vahratian A, Schieve LA, Reynolds MA, Jeng G. Live-birth rates and multiple-birth risk of assisted reproductive technology pregnancies conceived using thawed embryos, USA 1999-2000. Hum Reprod 2003;18:1442-8. https://doi.org/10.1093/humrep/deg284

9. Wright V, Schieve LA, Vahratian A, Reynolds MA. Monozygotic twinning associated with day 5 embryo transfer in pregnancies conceived after IVF. Hum Reprod 2004;19:1831-6. https://doi.org/10.1093/humrep/deh338

10. Kissin DM, Schieve LA, Reynolds MA. Multiple-birth risk associated with IVF and extended embryo culture: USA, 2001. Hum Reprod 2005;20:2215-23. https://doi.org/10.1093/humrep/dei025

11. Reynolds MA, Schieve LA. Trends in embryo transfer practices and multiple gestation for IVF procedures in the USA, 1996-2002. Hum Reprod 2006;21:694-700. https://doi.org/10.1093/humrep/dei363

12. Murray SR, Norman JE. Multiple pregnancies following assisted reproductive technologies - a happy consequence or double trouble? Semin Fetal Neonatal Med 2014;19:222-7. https://doi.org/10.1016/j. siny.2014.03.001

13. The ESHRE Capri Workshop Group. Multiple gestation pregnancy. Hum Reprod 2000;15:1856-64. https://doi.org/10.1093/humrep/15.8.1856

14. MacKay AP, Berg CJ, King JC, Duran C, Chang J. Pregnancy-related mortality among women with multifetal pregnancies. Obstet Gynecol 2006;107:563-8. https://doi.org/10.1097/01.AOG.0000200045.91015.c6
15. Reefhuis J, Honein MA, Schieve LA, Correa A, Hobbs CA, Rasmussen SA; National Birth Defects Prevention Study. Assisted reproductive technology and major structural birth defects in the United States. Hum Reprod 2009;24:360-6. https://doi.org/10.1093/humrep/den387

16. Fountain C, Zhang Y, Kissin DM, et al. Association between assisted reproductive technology conception and autism in California, 19972007. Am J Public Health 2015;105:963-71. https://doi.org/10.2105/ AJPH.2014.302383

17. Boulet SL, Kirby RS, Reefhuis J, et al.; States Monitoring Assisted Reproductive Technology (SMART) Collaborative. Assisted Reproductive Technology and Birth Defects Among Liveborn Infants in Florida, Massachusetts, and Michigan, 2000-2010. JAMA Pediatr 2016;170:e154934. https://doi.org/10.1001/jamapediatrics.2015.4934

18. Pandey S, Shetty A, Hamilton M, Bhattacharya S, Maheshwari A. Obstetric and perinatal outcomes in singleton pregnancies resulting from IVF/ICSI: a systematic review and meta-analysis. Hum Reprod Update 2012;18:485-503. https://doi.org/10.1093/humupd/dms018

19. Martin AS, Chang J, Zhang Y, et al.; States Monitoring Assisted Reproductive Technology (SMART) Collaborative. Perinatal outcomes among singletons after assisted reproductive technology with singleembryo or double-embryo transfer versus no assisted reproductive technology. Fertil Steril 2017;107:954-60. https://doi.org/10.1016/j. fertnstert.2017.01.024

20. Farr SL, Schieve LA, Jamieson DJ. Pregnancy loss among pregnancies conceived through assisted reproductive technology, United States, 1999-2002. Am J Epidemiol 2007;165:1380-8. https://doi. org/10.1093/aje/kwm035

21. National Center for Health Statistics. Vital statistics data available. Natality public use file and CD-ROM. Hyattsville, MD: National Center for Health Statistics. https://www.cdc.gov/nchs/data_access/ VitalStatsOnline.htm

22. Martin JA, Hamilton BE, Osterman MJ, Driscoll AK, Mathews TJ. Births: final data for 2015. Natl Vital Stat Rep 2017;66:1-70.

23. Kramer MR, Hogue CR. What causes racial disparities in very preterm birth? A biosocial perspective. Epidemiol Rev 2009;31:84-98. https:// doi.org/10.1093/ajerev/mxp003

24. US Census Bureau. Annual estimates of the resident population for selected age groups by sex for the United States, states, counties, and Puerto Rico Commonwealth and municipios: April 1, 2010 to July 1, 2015. Washington, DC: US Census Bureau, Population Division; 2015. https://factfinder.census.gov/faces/tableservices/jsf/pages/productview. xhtml?pid=PEP_2015_PEPAGESEX\&prodType=table

25. CDC; American Society for Reproductive Medicine; Society for Assisted Reproductive Technology; RESOLVE. 1996 assisted reproductive technology success rates. Atlanta, GA: US Department of Health and Human Services; 1998.

26. Sunderam S, Kissin DM, Crawford SB, et al. Assisted Reproductive Technology Surveillance-United States, 2014. MMWR Surveill Summ 2017;66(No. SS-6). https://doi.org/10.15585/mmwr.ss6606a1

27. Kissin DM, Kulkarni AD, Kushnir VA, Jamieson DJ; National ART Surveillance System Group. Number of embryos transferred after in vitro fertilization and good perinatal outcome. Obstet Gynecol 2014;123:239-47. https://doi.org/10.1097/AOG.0000000000000106

28. Stillman RJ, Richter KS, Jones HW Jr. Refuting a misguided campaign against the goal of single-embryo transfer and singleton birth in assisted reproduction. Hum Reprod 2013;28:2599-607. https://doi. org/10.1093/humrep/det317

29. Calhaz-Jorge C, de Geyter C, Kupka MS, et al.; European IVFMonitoring Consortium (EIM) for the European Society of Human Reproduction and Embryology (ESHRE). Assisted reproductive technology in Europe, 2012: results generated from European registers by ESHRE. Hum Reprod 2016;31:1638-52. https://doi.org/10.1093/ humrep/dew151 
30. Sunderam S, Kissin DM, Crawford SB, et al. Assisted Reproductive Technology Surveillance-United States, 2012. MMWR Surveill Summ 2015;64(No. SS-6).

31. Henne MB, Bundorf MK. Insurance mandates and trends in infertility treatments. Fertil Steril 2008;89:66-73. https://doi.org/10.1016/j. fertnstert.2007.01.167

32. Hamilton BH, McManus B. The effects of insurance mandates on choices and outcomes in infertility treatment markets. Health Econ 2012;21:994-1016. https://doi.org/10.1002/hec.1776

33. Boulet SL, Crawford S, Zhang Y, et al.; States Monitoring ART Collaborative. Embryo transfer practices and perinatal outcomes by insurance mandate status. Fertil Steril 2015;104:403-9.e1. https://doi. org/10.1016/j.fertnstert.2015.05.015

34. Practice Committee of the American Society for Reproductive Medicine; Practice Committee of the Society for Assisted Reproductive Technology. Criteria for number of embryos to transfer: a committee opinion. Fertil Steril 2013;99:44-6. https://doi.org/10.1016/j.fertnstert.2012.09.038

35. Practice Committee of the Society for Assisted Reproductive Technology; American Society for Reproductive Medicine. Guidelines on the number of embryos transferred. Fertil Steril 2004;82(Suppl 1):1-2. https://doi. org/10.1016/j.fertnstert.2004.07.937

36. Practice Committee of the Society for Assisted Reproductive Technology; Practice Committee of the American Society for Reproductive Medicine. Guidelines on number of embryos transferred. Fertil Steril 2006;86(Suppl 1):S51-2. https://doi.org/10.1016/j.fertnstert.2006.07.1473

37. Practice Committee of the Society for Assisted Reproductive Technology; Practice Committee of the American Society for Reproductive Medicine. Guidelines on number of embryos transferred. Fertil Steril 2008;90(Suppl):S163-4. https://doi.org/10.1016/j.fertnstert.2008.08.053

38. Practice Committee of the American Society for Reproductive Medicine; Practice Committee of the Society for Assisted Reproductive Technology. Guidelines on number of embryos transferred. Fertil Steril 2009;92:1518-9. https://doi.org/10.1016/j.fertnstert.2009.08.059

39. Penzias A, Bendikson K, Butts S, et al.; Practice Committee of the American Society for Reproductive Medicine; Practice Committee of the Society for Assisted Reproductive Technology. Guidance on the limits to the number of embryos to transfer: a committee opinion. Fertil Steril 2017;107:901-3. https://doi.org/10.1016/j.fertnstert.2017.02.107

40. Kissin DM, Kulkarni AD, Mneimneh A, et al.; National ART Surveillance System (NASS) Group. Embryo transfer practices and multiple births resulting from assisted reproductive technology: an opportunity for prevention. Fertil Steril 2015;103:954-61. https://doi. org/10.1016/j.fertnstert.2014.12.127

41. Coddington CC, Jensen JR. Multiple pregnancy: changing expectations for patients and patterns for physicians. Fertil Steril 2015;103:898-9. https://doi.org/10.1016/j.fertnstert.2015.01.027

42. Maheshwari A, Griffiths S, Bhattacharya S. Global variations in the uptake of single embryo transfer. Hum Reprod Update 2011;17:107-20. https://doi.org/10.1093/humupd/dmq028

43. Jain T, Harlow BL, Hornstein MD. Insurance coverage and outcomes of in vitro fertilization. N Engl J Med 2002;347:661-6. https://doi. org/10.1056/NEJMsa013491

44. Styer AK, Luke B, Vitek W, et al. Factors associated with the use of elective single-embryo transfer and pregnancy outcomes in the United States, 2004-2012. Fertil Steril 2016;106:80-9. https://doi. org/10.1016/j.fertnstert.2016.02.034

45. Kissin DM, Boulet SL, Jamieson DJ; Assisted Reproductive Technology Surveillance and Research Team. Fertility Treatments in the United States: Improving Access and Outcomes. Obstet Gynecol 2016;128:387-90. https://doi.org/10.1097/AOG.0000000000001419

46. Practice Committee of American Society for Reproductive Medicine. Multiple gestation associated with infertility therapy: an American Society for Reproductive Medicine Practice Committee opinion. Fertil Steril 2012;97:825-34. https://doi.org/10.1016/j.fertnstert.2011.11.048
47. Behrman RE, Butler AS, editors. Preterm birth: causes, consequences, and prevention. Washington, DC: National Academies Press; 2007.

48. Boulet SL, Schieve LA, Nannini A, et al. Perinatal outcomes of twin births conceived using assisted reproduction technology: a populationbased study. Hum Reprod 2008;23:1941-8. https://doi.org/10.1093/ humrep/den 169

49. Wright VC, Schieve LA, Reynolds MA, Jeng G. Assisted reproductive technology surveillance-United States, 2000. MMWR Surveill Summ 2003;52(No. SS-9). Erratum in: MMWR Morb Mortal Wkly Rep 2003;52:942.

50. Grobman WA, Milad MP, Stout J, Klock SC. Patient perceptions of multiple gestations: an assessment of knowledge and risk aversion. Am J Obstet Gynecol 2001;185:920-4. https://doi.org/10.1067/mob.2001.117305

51. Blennborn M, Nilsson S, Hillervik C, Hellberg D. The couple's decisionmaking in IVF: one or two embryos at transfer? Hum Reprod 2005;20:1292-7. https://doi.org/10.1093/humrep/deh785

52. Pinborg A, Loft A, Schmidt L, Andersen AN. Attitudes of IVF/ICSItwin mothers towards twins and single embryo transfer. Hum Reprod 2003;18:621-7. https://doi.org/10.1093/humrep/deg145

53. Ryan GL, Sparks AE, Sipe CS, Syrop CH, Dokras A, Van Voorhis BJ. A mandatory single blastocyst transfer policy with educational campaign in a United States IVF program reduces multiple gestation rates without sacrificing pregnancy rates. Fertil Steril 2007;88:354-60. https://doi. org/10.1016/j.fertnstert.2007.03.001

54. Hope N, Rombauts L. Can an educational DVD improve the acceptability of elective single embryo transfer? A randomized controlled study. Fertil Steril 2010;94:489-95. https://doi.org/10.1016/j. fertnstert.2009.03.080

55. Murray S, Shetty A, Rattray A, Taylor V, Bhattacharya S. A randomized comparison of alternative methods of information provision on the acceptability of elective single embryo transfer. Hum Reprod 2004;19:911-6. https://doi.org/10.1093/humrep/deh176

56. Lemos EV, Zhang D, Van Voorhis BJ, Hu XH. Healthcare expenses associated with multiple vs singleton pregnancies in the United States. Am J Obstet Gynecol 2013;209:586.e1-11. https://doi.org/10.1016/j. ajog.2013.10.005

57. Henne MB, Bundorf MK. The effects of competition on assisted reproductive technology outcomes. Fertil Steril 2010;93:1820-30. https://doi.org/10.1016/j.fertnstert.2008.02.159

58. Luke B, Brown MB, Wantman E, et al. Application of a validated prediction model for in vitro fertilization: comparison of live birth rates and multiple birth rates with 1 embryo transferred over 2 cycles vs 2 embryos in 1 cycle. Am J Obstet Gynecol 2015;212:676.e1-7. https:// doi.org/10.1016/j.ajog.2015.02.005

59. Fiddelers AAA, Severens JL, Dirksen CD, Dumoulin JC, Land JA, Evers JL. Economic evaluations of single- versus double-embryo transfer in IVF. Hum Reprod Update 2007;13:5-13. https://doi.org/10.1093/ humupd/dml053

60. Crawford S, Boulet SL, Mneimneh AS, et al. Costs of achieving live birth from assisted reproductive technology: a comparison of sequential single and double embryo transfer approaches. Fertil Steril 2016;105:444-50. https://doi.org/10.1016/j.fertnstert.2015.10.032

61. Kulkarni AD, Jamieson DJ, Jones HW Jr, et al. Fertility treatments and multiple births in the United States. N Engl J Med 2013;369:2218-25. https://doi.org/10.1056/NEJMoa1301467

62. Callaghan WM, MacDorman MF, Rasmussen SA, Qin C, Lackritz EM. The contribution of preterm birth to infant mortality rates in the United States. Pediatrics 2006;118:1566-73. https://doi.org/10.1542/ peds.2006-0860

63. Tanner K, Sabrine N, Wren C. Cardiovascular malformations among preterm infants. Pediatrics 2005;116:e833-8. https://doi.org/10.1542/ peds.2005-0397

64. Rasmussen SA, Moore CA, Paulozzi LJ, Rhodenhiser EP. Risk for birth defects among premature infants: a population-based study. J Pediatr 2001;138:668-73. https://doi.org/10.1067/mpd.2001.112249 
65. Kissin DM, Jamieson DJ, Barfield WD. Monitoring health outcomes of assisted reproductive technology. N Engl J Med 2014;371:91-3. https://doi.org/10.1056/NEJMc1404371

66. CDC. National public health action plan for the detection, prevention, and management of infertility. Atlanta, GA: CDC; 2014. https://www. cdc.gov/reproductivehealth/Infertility/PDF/DRH_NAP_Final_508.pdf

67. Martin JA, Hamilton BE, Osterman MJK. Three decades of twin births in the United States, 1980-2009. NCHS Data Brief 2012;80:1-8.

68. D’Angelo DV, Whitehead N, Helms K, Barfield W, Ahluwalia IB. Birth outcomes of intended pregnancies among women who used assisted reproductive technology, ovulation stimulation, or no treatment. Fertil Steril 2011;96:314-320.e2. https://doi.org/10.1016/j.fertnstert.2011.05.073
69. Barradas DT, Barfield WD, Wright V, D’Angelo D, Manning SE, Schieve LA. Assessment of assisted reproductive technology use questions: Pregnancy Risk Assessment Monitoring System Survey, 2004. Public Health Rep 2012;127:516-23. https://doi.org/10.1177/003335491212700507

70. Kissin DM, Jamieson DJ, Barfield WD. Assisted reproductive technology program reporting. [Letter]. JAMA 2011;306:2564, author reply 2564-5. https://doi.org/10.1001/jama.2011.1843

71. Mneimneh AS, Boulet SL, Sunderam S, et al.; States Monitoring ART (SMART) Collaborative. States Monitoring Assisted Reproductive Technology (SMART) Collaborative: data collection, linkage, dissemination, and use. J Womens Health (Larchmt) 2013;22:571-7. https://doi.org/10.1089/jwh.2013.4452 
TABLE 1. Number* and outcomes of assisted reproductive technology procedures, by female patient's reporting area of residence ${ }^{\dagger}$ at time of treatment — United States and Puerto Rico, 2015

\begin{tabular}{|c|c|c|c|c|c|c|c|c|c|}
\hline $\begin{array}{l}\text { Patient's reporting } \\
\text { area of residence }\end{array}$ & $\begin{array}{l}\text { No. of ART } \\
\text { clinics } \S\end{array}$ & $\begin{array}{l}\text { No. of ART } \\
\text { procedures } \\
\text { performed }\end{array}$ & $\begin{array}{c}\text { No. of ART } \\
\text { embryo-transfer } \\
\text { procedures }\end{array}$ & $\begin{array}{c}\text { No. of ART } \\
\text { pregnancies }\end{array}$ & $\begin{array}{l}\text { No. of ART } \\
\text { live-birth } \\
\text { deliveries }\end{array}$ & $\begin{array}{l}\text { No. of ART } \\
\text { singleton } \\
\text { live-birth } \\
\text { deliveries }\end{array}$ & $\begin{array}{c}\text { No. of ART } \\
\text { multiple } \\
\text { live-birth } \\
\text { deliveries }\end{array}$ & $\begin{array}{l}\text { No. of ART } \\
\text { live-born } \\
\text { infants }\end{array}$ & $\begin{array}{l}\text { ART procedures } \\
\text { per } 1 \text { million } \\
\text { women aged } \\
15-44 \text { yrs }^{* *}\end{array}$ \\
\hline Alabama & 6 & 1,092 & 850 & 436 & 362 & 265 & 97 & 465 & $1,138.7$ \\
\hline Alaska & 0 & 135 & 111 & 70 & 60 & 41 & 19 & 80 & 921.4 \\
\hline Arizona $^{\dagger \dagger}$ & 12 & 2,393 & 1,959 & 1,052 & 823 & 630 & 193 & 1,026 & $1,813.0$ \\
\hline Arkansas & 1 & 528 & 417 & 190 & 167 & 124 & 43 & 209 & 915.9 \\
\hline California $^{\dagger \dagger}$ & 65 & 23,198 & 18,122 & 9,556 & 7,802 & 6,447 & 1,355 & 9,176 & $2,869.4$ \\
\hline Colorado $^{+\dagger}$ & 8 & 2,196 & 1,822 & 1,189 & 990 & 794 & 196 & 1,188 & $1,984.6$ \\
\hline Connecticut & 8 & 3,262 & 2,410 & 1,377 & 1,118 & 875 & 243 & 1,367 & $4,792.6$ \\
\hline Delaware & 2 & 714 & 508 & 306 & 255 & 231 & 24 & 279 & $3,948.9$ \\
\hline District of Columbia & 3 & 1,220 & 930 & 404 & 335 & 301 & 34 & 369 & $6,726.2$ \\
\hline Florida & 30 & 8,042 & 6,178 & 3,065 & 2,481 & 1,917 & 564 & 3,054 & $2,150.1$ \\
\hline Georgia & 8 & 3,904 & 3,153 & 1,656 & 1,316 & 1,123 & 193 & 1,515 & $1,841.6$ \\
\hline Hawaii ${ }^{\dagger \dagger}$ & 5 & 1,043 & 779 & 403 & 322 & 224 & 98 & 424 & $3,889.1$ \\
\hline Idaho & 1 & 543 & 453 & 271 & 227 & 171 & 56 & 285 & $1,708.6$ \\
\hline Illinois & 28 & 12,294 & 9,434 & 4,532 & 3,634 & 2,889 & 745 & 4,382 & $4,769.5$ \\
\hline Indiana & 10 & 2,144 & 1,733 & 822 & 678 & 507 & 171 & 855 & $1,653.7$ \\
\hline lowa & 2 & 1,342 & 1,110 & 692 & 593 & 482 & 111 & 706 & $2,280.8$ \\
\hline Kansas & 4 & 1,040 & 761 & 410 & 339 & 271 & 68 & 409 & $1,856.7$ \\
\hline Kentucky & 5 & 1,238 & 1,041 & 508 & 409 & 316 & 93 & 503 & $1,453.7$ \\
\hline Louisiana & 5 & 1,425 & 972 & 507 & 411 & 315 & 96 & 508 & $1,509.6$ \\
\hline Maine & 1 & 452 & 383 & 186 & 157 & 136 & 21 & 178 & $1,947.3$ \\
\hline Maryland & 7 & 6,248 & 4,907 & 2,268 & 1,797 & 1,582 & 215 & 2,014 & $5,204.2$ \\
\hline Massachusetts & 8 & 9,388 & 7,866 & 3,626 & 2,911 & 2,579 & 332 & 3,241 & $6,832.8$ \\
\hline Michigan & 13 & 3,868 & 3,186 & 1,584 & 1,288 & 917 & 371 & 1,666 & $2,056.7$ \\
\hline Minnesota & 5 & 2,431 & 2,098 & 1,167 & 960 & 730 & 230 & 1,197 & $2,306.3$ \\
\hline Mississippi & 2 & 616 & 458 & 249 & 206 & 152 & 54 & 258 & $1,027.6$ \\
\hline Missouri & 8 & 2,254 & 1,843 & 916 & 776 & 593 & 183 & 963 & $1,915.8$ \\
\hline Montana & 1 & 293 & 230 & 132 & 109 & 75 & 34 & 143 & $1,567.5$ \\
\hline Nebraska & 2 & 751 & 573 & 323 & 275 & 212 & 63 & 338 & $2,049.8$ \\
\hline Nevada & 5 & 1,216 & 1,044 & 595 & 494 & 394 & 100 & 594 & $2,119.1$ \\
\hline New Hampshire ${ }^{\dagger \dagger}$ & 1 & 818 & 680 & 310 & 260 & 223 & 37 & 297 & $3,375.5$ \\
\hline New Jersey & 20 & 9,591 & 7,238 & 3,996 & 3,269 & 2,767 & 502 & 3768 & $5,580.7$ \\
\hline New Mexico & 1 & 215 & 170 & 91 & 73 & 59 & 14 & 88 & 543.6 \\
\hline New York & 38 & 21,298 & 16,515 & 7,225 & 5,690 & 4,725 & 965 & 6,671 & $5,276.8$ \\
\hline North Carolina & 11 & 3,871 & 2,942 & 1,643 & 1,352 & 1,057 & 295 & 1,654 & $1,943.4$ \\
\hline North Dakota & 1 & 352 & 304 & 140 & 118 & 74 & 44 & 162 & $2,377.0$ \\
\hline Ohio & 14 & 4,250 & 3,589 & 1,811 & 1,498 & 1,102 & 396 & 1,903 & $1,925.0$ \\
\hline Oklahoma & 3 & 879 & 745 & 396 & 319 & 230 & 89 & 409 & $1,144.0$ \\
\hline Oregon & 3 & 1,261 & 994 & 619 & 524 & 394 & 130 & 657 & $1,603.6$ \\
\hline Pennsylvania & 16 & 6,683 & 5,310 & 2,445 & 1,991 & 1,658 & 333 & 2,326 & $2,783.6$ \\
\hline Puerto Rico & 3 & 229 & 206 & 99 & 71 & 46 & 25 & 97 & 329.3 \\
\hline Rhode Island & 1 & 779 & 648 & 264 & 203 & 162 & 41 & 247 & $3,717.3$ \\
\hline South Carolina & 4 & 1,448 & 1,145 & 655 & 535 & 381 & 154 & 698 & $1,521.1$ \\
\hline South Dakota & 1 & 285 & 224 & 117 & 102 & 70 & 32 & 138 & $1,806.0$ \\
\hline Tennessee & 9 & 1,660 & 1,283 & 706 & 581 & 452 & 129 & 713 & $1,277.2$ \\
\hline Texas & 43 & 14,342 & 10,903 & 5,938 & 4,896 & 3,741 & 1,155 & 6,056 & $2,494.9$ \\
\hline $\mathrm{Utah}^{+\dagger}$ & 4 & 1,838 & 1,585 & 954 & 794 & 565 & 229 & 1,023 & $2,821.9$ \\
\hline Vermont & 2 & 284 & 217 & 95 & 82 & 67 & 15 & 98 & $2,456.8$ \\
\hline Virginia & 12 & 5,966 & 4,755 & 2,265 & 1,838 & 1,545 & 293 & 2,133 & $3,540.9$ \\
\hline Washington & 12 & 3,445 & 2,706 & 1,470 & 1,202 & 1,013 & 189 & 1,395 & $2,430.8$ \\
\hline West Virginia & 3 & 305 & 253 & 118 & 104 & 76 & 28 & 134 & 914.6 \\
\hline Wisconsin & 7 & 2,035 & 1,623 & 822 & 704 & 521 & 183 & 885 & $1,874.9$ \\
\hline Wyoming & 0 & 152 & 125 & 66 & 55 & 41 & 14 & 68 & $1,373.5$ \\
\hline Nonresident & NA & 4,855 & 3,795 & 2,133 & 1,778 & 1,423 & 355 & 2,140 & —§§ \\
\hline Total & 464 & 182,111 & 143,286 & 72,870 & 59,334 & 47,685 & 11,649 & 71,152 & $2,832.1$ \\
\hline
\end{tabular}

Abbreviations: $\mathrm{ART}=$ assisted reproductive technology; $\mathrm{NA}=$ not applicable.

* Excludes 45,779 egg/embryo-freezing and embryo-banking procedures, 4,003 egg-thaw procedures, and 43 procedures performed in territories not included in this report.

${ }^{\dagger}$ In cases of missing residency data ( $\left.0.8 \%\right)$, the patient's residence was assigned as the location in which the ART procedure was performed.

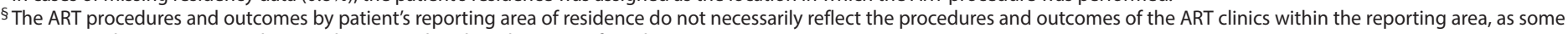
patients seek treatment at a clinic in a location other than their area of residence.

" Embryo-transfer procedures include all procedures performed in which an attempt was made to transfer at least one embryo.

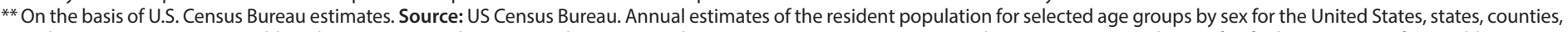

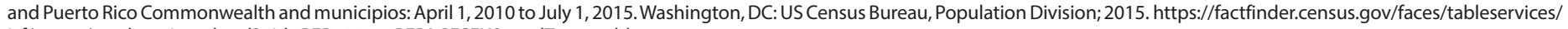
jsf/pages/productview.xhtml?pid=PEP_2015_PEPAGESEX\&prodType=table.

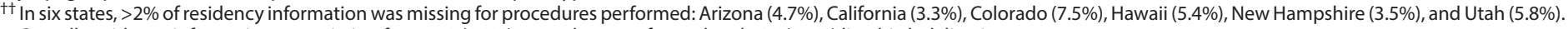
Overall, residency information was missing for 1,468 (0.8\%) procedures performed and $623(1.1 \%)$ live-birth deliveries.

$\S \S$ Non-U.S. residents excluded from rate because the appropriate denominators were not available. 
TABLE 2. Number of assisted reproductive technology embryo-transfer procedures* among patients who used fresh embryos from their own fresh eggs, by female patient's age group and reporting area of residence ${ }^{\dagger}$ at time of treatment — United States and Puerto Rico, 2015

\begin{tabular}{|c|c|c|c|c|c|c|c|c|c|}
\hline \multirow[b]{2}{*}{$\begin{array}{l}\text { Patient's reporting } \\
\text { area of residence }\end{array}$} & \multicolumn{3}{|c|}{$<35$ yrs } & \multicolumn{3}{|c|}{$35-37$ yrs } & \multicolumn{3}{|c|}{$>37$ yrs } \\
\hline & $\begin{array}{l}\text { No. of } \\
\text { embryo-transfer } \\
\text { procedures }\end{array}$ & $\begin{array}{l}\text { Average no. of } \\
\text { embryos } \\
\text { transferred }\end{array}$ & $\mathrm{eSET}^{\S}(\%)$ & $\begin{array}{c}\text { No. of } \\
\text { embryo-transfer } \\
\text { procedures }\end{array}$ & $\begin{array}{l}\text { Average no. of } \\
\text { embryos } \\
\text { transferred }\end{array}$ & eSET (\%) & $\begin{array}{c}\text { No. of } \\
\text { embryo-transfer } \\
\text { procedures }\end{array}$ & $\begin{array}{l}\text { Average no. of } \\
\text { embryos } \\
\text { transferred }\end{array}$ & eSET (\%) \\
\hline Alabama & 266 & 1.8 & 19.4 & 75 & 2.0 & 4.3 & 64 & 2.5 & 0 \\
\hline Alaska & 16 & -9 & —า & 19 & - & - & 10 & - & - \\
\hline Arizona** & 325 & 1.8 & 20.2 & 117 & 2.0 & 9.6 & 164 & 2.4 & 4.3 \\
\hline Arkansas & 158 & 1.8 & 13.1 & 44 & 1.9 & 8.1 & 20 & 1.8 & 7.7 \\
\hline California** & 2,196 & 1.6 & 36.1 & 1,339 & 1.9 & 21.5 & 2,273 & 2.5 & 4.4 \\
\hline Colorado** & 181 & 1.7 & 26.7 & 73 & 1.8 & 16.1 & 69 & 2.2 & 5.3 \\
\hline Connecticut & 621 & 1.5 & 46.5 & 255 & 1.8 & 18.5 & 385 & 2.2 & 5.2 \\
\hline Delaware & 67 & 1.1 & 88.1 & 22 & 1.5 & 61.9 & 23 & 2.3 & 14.3 \\
\hline District of Columbia & 93 & 1.4 & 56.4 & 74 & 1.6 & 34.5 & 237 & 2.0 & 8.0 \\
\hline Florida & 1,167 & 1.7 & 26.4 & 613 & 1.9 & 10.5 & 891 & 2.2 & 2.8 \\
\hline Georgia & 603 & 1.6 & 39.7 & 274 & 1.7 & 22.3 & 292 & 2.4 & 4.8 \\
\hline Hawaii ${ }^{* *}$ & 96 & 1.8 & 22.5 & 59 & 1.9 & 11.3 & 150 & 2.5 & 3.1 \\
\hline Idaho & 132 & 1.7 & 21.3 & 34 & 1.7 & 21.4 & 15 & -9 & - \\
\hline Illinois & 2,110 & 1.7 & 30.4 & 928 & 1.9 & 16.1 & 1,319 & 2.3 & 2.8 \\
\hline Indiana & 562 & 1.8 & 16.1 & 169 & 1.9 & 7.9 & 157 & 2.3 & 3.0 \\
\hline lowa & 295 & 1.5 & 46.0 & 90 & 1.6 & 36.7 & 79 & 2.0 & 6.0 \\
\hline Kansas & 144 & 1.6 & 36.6 & 52 & 1.7 & 21.7 & 48 & 2.2 & 2.3 \\
\hline Kentucky & 349 & 1.8 & 25.2 & 124 & 2.0 & 6.8 & 78 & 2.4 & 2.9 \\
\hline Louisiana & 203 & 1.8 & 17.7 & 63 & 1.9 & 12.5 & 66 & 2.1 & 10.5 \\
\hline Maine & 105 & 1.2 & 72.2 & 42 & 1.5 & 47.2 & 61 & 1.9 & 10.4 \\
\hline Maryland & 1,107 & 1.3 & 63.0 & 527 & 1.5 & 40.7 & 954 & 2.0 & 8.4 \\
\hline Massachusetts & 1,683 & 1.3 & 70.3 & 996 & 1.5 & 47.7 & 1,606 & 2.4 & 9.5 \\
\hline Michigan & 853 & 1.8 & 19.2 & 310 & 2.0 & 11.6 & 385 & 2.3 & 4.6 \\
\hline Minnesota & 629 & 1.6 & 35.1 & 214 & 1.7 & 20.2 & 184 & 2.1 & 4.6 \\
\hline Mississippi & 111 & 1.7 & 26.0 & 29 & 1.9 & 11.1 & 23 & 2.1 & 0 \\
\hline Missouri & 517 & 1.8 & 13.6 & 156 & 1.9 & 8.5 & 146 & 2.6 & 2.4 \\
\hline Montana & 57 & 1.6 & 26.5 & 23 & 1.8 & 11.1 & 17 & - & - \\
\hline Nebraska & 146 & 1.7 & 22.2 & 38 & 1.8 & 6.1 & 40 & 2.2 & 5.7 \\
\hline Nevada & 152 & 1.6 & 26.4 & 72 & 1.7 & 14.5 & 73 & 1.8 & 5.4 \\
\hline New Hampshire** & 161 & 1.4 & 62.9 & 98 & 1.6 & 38.3 & 97 & 2.5 & 3.9 \\
\hline New Jersey & 1,258 & 1.5 & 45.5 & 670 & 1.6 & 31.8 & 965 & 2.1 & 12.9 \\
\hline New Mexico & 15 & — & — & 6 & — & —? & 10 & — & - \\
\hline New York & 2,798 & 1.6 & 36.3 & 1,598 & 1.9 & 18.7 & 3,246 & 2.3 & 5.5 \\
\hline North Carolina & 599 & 1.6 & 36.0 & 256 & 1.9 & 13.1 & 315 & 2.3 & 3.0 \\
\hline North Dakota & 112 & 1.8 & 17.2 & 30 & 1.9 & 7.1 & 17 & — & — \\
\hline Ohio & 1,091 & 1.8 & 19.4 & 397 & 1.9 & 7.7 & 399 & 2.3 & 3.4 \\
\hline Oklahoma & 289 & 1.8 & 13.0 & 89 & 2.0 & 8.6 & 83 & 2.3 & 4.0 \\
\hline Oregon & 150 & 1.7 & 26.6 & 67 & 1.8 & 23.4 & 53 & 1.9 & 13.6 \\
\hline Pennsylvania & 1,211 & 1.6 & 36.6 & 571 & 1.8 & 21.0 & 585 & 2.2 & 6.0 \\
\hline Puerto Rico & 56 & 2.0 & 11.3 & 37 & 2.2 & 0 & 62 & 2.4 & 0 \\
\hline Rhode Island & 159 & 1.5 & 45.5 & 110 & 1.8 & 18.5 & 127 & 2.8 & 0 \\
\hline South Carolina & 208 & 1.7 & 23.1 & 107 & 2 & 7.0 & 97 & 2.4 & 2.3 \\
\hline South Dakota & 71 & 1.7 & 21.5 & 15 & — & - & 8 & —ף & —ก \\
\hline Tennessee & 272 & 1.7 & 27.5 & 108 & 1.9 & 9.5 & 103 & 2.2 & 1.2 \\
\hline Texas & 1,817 & 1.7 & 25.3 & 723 & 1.9 & 10.3 & 881 & 2.2 & 2.7 \\
\hline Utah** & 523 & 1.8 & 20.7 & 151 & 1.9 & 11.3 & 120 & 2.1 & 5.0 \\
\hline Vermont & 48 & 1.8 & 26.1 & 31 & 1.7 & 34.5 & 34 & 2.2 & 10.0 \\
\hline Virginia & 904 & 1.5 & 42.0 & 510 & 1.6 & 28.0 & 732 & 2.0 & 6.8 \\
\hline Washington & 452 & 1.5 & 43.3 & 222 & 1.7 & 29.4 & 264 & 2.1 & 3.6 \\
\hline West Virginia & 95 & 1.8 & 17.3 & 32 & 1.9 & 16.0 & 18 & - & - \\
\hline Wisconsin & 378 & 1.6 & 35.6 & 129 & 1.9 & 12.1 & 106 & 2.2 & 4.5 \\
\hline Wyoming & 32 & 1.8 & 16.1 & 10 & —ף & —? & 10 & — & - \\
\hline Nonresident & 299 & 1.6 & 34.4 & 145 & 1.7 & 20.2 & 268 & 2.2 & 7.4 \\
\hline Total & 27,942 & 1.6 & 34.7 & 12,943 & 1.8 & 20.8 & 18,429 & 2.3 & 2.3 \\
\hline
\end{tabular}

Abbreviation: eSET = elective single-embryo transfer.

* Includes all procedures in which at least one embryo was transferred.

$\dagger$ In cases of missing residency data $(0.8 \%)$, the patient's residence was assigned as the location in which the assisted reproductive technology procedure was performed.

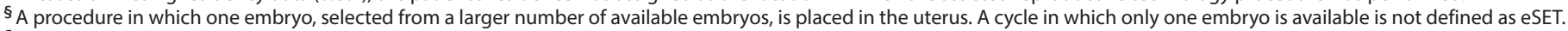

"Estimates on the basis of $\mathrm{N}<20$ in the denominator have been suppressed because such rates are considered unstable.

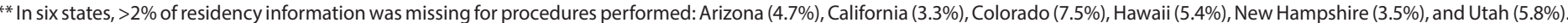

Overall, residency information was missing for 1,468 (0.8\%) procedures performed and $623(1.1 \%)$ live-birth deliveries. 
TABLE 3. Number, proportion, and percentage of infants born with use of assisted reproductive technology, by female patient's reporting area of residence* at time of treatment — United States and Puerto Rico, $2015^{\dagger}$

\begin{tabular}{|c|c|c|c|c|c|c|}
\hline \multirow[b]{2}{*}{$\begin{array}{l}\text { Patient's reporting } \\
\text { area of residence }\end{array}$} & \multirow[b]{2}{*}{$\begin{array}{l}\text { Total no. of } \\
\text { infants born }\end{array}$} & \multirow[b]{2}{*}{$\begin{array}{l}\text { No. of ART } \\
\text { infants born }\end{array}$} & \multirow{2}{*}{$\begin{array}{c}\text { Proportion of } \\
\text { ART infants } \\
\text { among all infants } \\
\text { (\%) }\end{array}$} & \multirow{2}{*}{$\begin{array}{c}\begin{array}{c}\text { Singleton infants among } \\
\text { ART infants }\end{array} \\
\text { No. (\%) }\end{array}$} & \multirow{2}{*}{$\begin{array}{c}\begin{array}{c}\text { Singleton infants among } \\
\text { all infants } \S\end{array} \\
\text { No. (\%) }\end{array}$} & \multirow{2}{*}{$\begin{array}{c}\text { Proportion of ART } \\
\text { singleton infants among } \\
\text { all singleton infants (\%) }\end{array}$} \\
\hline & & & & & & \\
\hline Alabama & 59,657 & 435 & 0.7 & $250(57.5)$ & $57,444(96.3)$ & 0.4 \\
\hline Alaska & 11,282 & 87 & 0.8 & 46 (52.9) & 10,945 (97.0) & 0.4 \\
\hline Arizonaף & 85,351 & 962 & 1.1 & $576(59.9)$ & $82,823(97.0)$ & 0.7 \\
\hline Arkansas & 38,886 & 217 & 0.6 & $124(57.1)$ & $37,624(96.8)$ & 0.3 \\
\hline California" & 491,748 & 8,839 & 1.8 & $5,853(66.2)$ & $476,094(96.8)$ & 1.2 \\
\hline Colorado & 66,581 & 1,075 & 1.6 & 751 (69.9) & $64,511(96.9)$ & 1.2 \\
\hline Connecticut & 35,746 & 1,299 & 3.6 & $835(64.3)$ & 34,271 (95.9) & 2.4 \\
\hline Delaware & 11,166 & 262 & 2.3 & $214(81.7)$ & $10,798(96.7)$ & 2.0 \\
\hline District of Columbia & 9,578 & 359 & 3.7 & $281(78.3)$ & $9,127(95.3)$ & 3.1 \\
\hline Florida & 224,269 & 2,966 & 1.3 & $1,798(60.6)$ & $216,770(96.7)$ & 0.8 \\
\hline Georgia & 131,404 & 1,582 & 1.2 & $1,089(68.8)$ & $126,872(96.6)$ & 0.9 \\
\hline Hawaiiๆ & 18,420 & 506 & 2.7 & $274(54.2)$ & $17,900(97.2)$ & 1.5 \\
\hline Idaho & 22,827 & 247 & 1.1 & $105(42.5)$ & $22,067(96.7)$ & 0.5 \\
\hline Illinois & 158,116 & 4,056 & 2.6 & $2,551(62.9)$ & $151,956(96.1)$ & 1.7 \\
\hline Indiana & 84,040 & 842 & 1.0 & $448(53.2)$ & 81,164 (96.6) & 0.6 \\
\hline lowa & 39,482 & 646 & 1.6 & $417(64.6)$ & $38,136(96.6)$ & 1.1 \\
\hline Kansas & 39,154 & 396 & 1.0 & $226(57.1)$ & 37,907 (96.8) & 0.6 \\
\hline Kentucky & 55,971 & 479 & 0.9 & $271(56.6)$ & $54,086(96.6)$ & 0.5 \\
\hline Louisiana & 64,692 & 504 & 0.8 & 301 (59.7) & $62,442(96.5)$ & 0.5 \\
\hline Maine & 12,607 & 140 & 1.1 & 97 (69.3) & $12,219(96.9)$ & 0.8 \\
\hline Maryland & 73,616 & 1,891 & 2.6 & $1,468(77.6)$ & $71,026(96.5)$ & 2.1 \\
\hline Massachusetts & 71,492 & 3,248 & 4.5 & $2,467(76.0)$ & $68,764(96.2)$ & 3.6 \\
\hline Michigan & 113,312 & 1,474 & 1.3 & $859(58.3)$ & $109,084(96.3)$ & 0.8 \\
\hline Minnesota & 69,834 & 1,109 & 1.6 & $684(61.7)$ & $67,355(96.5)$ & 1.0 \\
\hline Mississippi & 38,394 & 260 & 0.7 & $137(52.7)$ & $37,023(96.4)$ & 0.4 \\
\hline Missouri & 75,061 & 896 & 1.2 & $542(60.5)$ & $72,301(96.3)$ & 0.7 \\
\hline Montana & 12,583 & 132 & 1.0 & $82(62.1)$ & $12,145(96.5)$ & 0.7 \\
\hline Nebraska & 26,679 & 381 & 1.4 & $223(58.5)$ & $25,615(96.0)$ & 0.9 \\
\hline Nevada & 36,298 & 531 & 1.5 & $332(62.5)$ & $35,099(96.7)$ & 0.9 \\
\hline New Hampshireף & 12,433 & 306 & 2.5 & $217(70.9)$ & $11,973(96.3)$ & 1.8 \\
\hline New Jersey & 103,127 & 3,604 & 3.5 & $2,467(68.5)$ & $98,874(95.9)$ & 2.5 \\
\hline New Mexico & 25,816 & 119 & 0.5 & $85(71.4)$ & $25,190(97.6)$ & 0.3 \\
\hline New York & 237,274 & 6,435 & 2.7 & 4,367 (67.9) & $228,485(96.3)$ & 1.9 \\
\hline North Carolina & 120,843 & 1,564 & 1.3 & $994(63.6)$ & $116,592(96.5)$ & 0.9 \\
\hline North Dakota & 11,314 & 138 & 1.2 & $80(58.0)$ & 10,963 (96.9) & 0.7 \\
\hline Ohio & 139,264 & 1,725 & 1.2 & $990(57.4)$ & $134,262(96.4)$ & 0.7 \\
\hline Oklahoma & 53,122 & 415 & 0.8 & $223(53.7)$ & $51,412(96.8)$ & 0.4 \\
\hline Oregon & 45,655 & 776 & 1.7 & $424(54.6)$ & $44,082(96.6)$ & 1.0 \\
\hline Pennsylvania & 141,047 & 2,300 & 1.6 & $1,575(68.5)$ & $136,001(96.4)$ & 1.2 \\
\hline Puerto Rico & 31,157 & 101 & 0.3 & 45 (44.6) & $30,434(97.7)$ & 0.1 \\
\hline Rhode Island & 10,993 & 268 & 2.4 & $174(64.9)$ & $10,590(96.3)$ & 1.6 \\
\hline South Carolina & 58,139 & 611 & 1.1 & $358(58.6)$ & $56,011(96.3)$ & 0.6 \\
\hline South Dakota & 12,336 & 104 & 0.8 & $74(71.2)$ & $11,946(96.8)$ & 0.6 \\
\hline Tennessee & 81,685 & 694 & 0.8 & $428(61.7)$ & $78,875(96.6)$ & 0.5 \\
\hline Texas & 403,618 & 5,778 & 1.4 & 3,445 (59.6) & $390,594(96.8)$ & 0.9 \\
\hline Utahף & 50,778 & 954 & 1.9 & $504(52.8)$ & $48,940(96.4)$ & 1.0 \\
\hline Vermont & 5,903 & 69 & 1.2 & $49(71.0)$ & $5,700(96.6)$ & 0.9 \\
\hline Virginia & 103,303 & 2,055 & 2.0 & $1,492(72.6)$ & $99,693(96.5)$ & 1.5 \\
\hline Washington & 88,990 & 1,390 & 1.6 & $980(70.5)$ & $86,107(96.8)$ & 1.1 \\
\hline West Virginia & 19,805 & 143 & 0.7 & $82(57.3)$ & $19,198(96.9)$ & 0.4 \\
\hline Wisconsin & 67,041 & 847 & 1.3 & $488(57.6)$ & $64,669(96.5)$ & 0.8 \\
\hline Wyoming & 7,765 & 81 & 1.0 & $43(53.1)$ & $7,494(96.5)$ & 0.6 \\
\hline Total & $4,009,654$ & 66,298 & 1.7 & $42,885(64.7)$ & $3,871,653(96.6)$ & 1.1 \\
\hline
\end{tabular}

Abbreviation: $\mathrm{ART}=$ assisted reproductive technology

* In cases of missing residency data $(0.8 \%)$, the patient's residence was assigned as the location in which the ART procedure was performed.

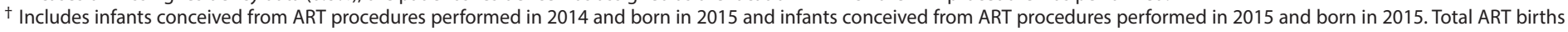
exclude nonresidents.

$\S$ U.S. births include nonresidents. Source: Martin JA, Hamilton BE, Osterman MJ, Driscoll AK, Mathews TJ. Births: final data for 2015. Natl Vital Stat Rep 2017;66:1-70.

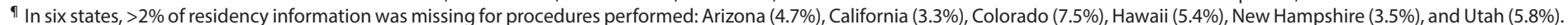
Overall, residency information was missing for 1,468 (0.8\%) procedures performed and $623(1.1 \%)$ live-birth deliveries. 
TABLE 4. Number, percentage, and proportion of multiple-birth infants, twins, and triplets and higher-order infants born with use of assisted reproductive technology procedures, by female patient's reporting area of residence* at time of treatment - United States and Puerto Rico, $2015^{\dagger}$

\begin{tabular}{|c|c|c|c|c|c|c|c|c|c|}
\hline $\begin{array}{l}\text { Patient's reporting } \\
\text { area of residence }\end{array}$ & $\begin{array}{c}\text { Multiple-birth } \\
\text { infants } \\
\text { among } \\
\text { ART infants } \\
\end{array}$ & $\begin{array}{l}\text { Multiple-birth } \\
\text { infants } \\
\text { among } \\
\text { all infants } \\
\end{array}$ & $\begin{array}{l}\text { Proportion of } \\
\text { ART } \\
\text { multiple-birth } \\
\text { infants among } \\
\text { all multiple- } \\
\text { birth } \\
\text { infants (\%) }\end{array}$ & 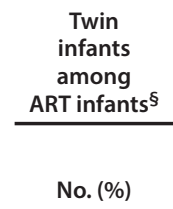 & $\begin{array}{c}\text { Twin } \\
\text { infants } \\
\text { among } \\
\text { all infants? }\end{array}$ & $\begin{array}{l}\text { Proportion } \\
\text { of ART } \\
\text { twin } \\
\text { infants } \\
\text { among all } \\
\text { twin } \\
\text { infants (\%) }\end{array}$ & $\begin{array}{c}\text { Triplets and } \\
\text { higher-order } \\
\text { infants among } \\
\text { ART infants } \$\end{array}$ & $\begin{array}{c}\text { Triplets and } \\
\text { higher-order } \\
\text { infants among } \\
\text { all infants }\end{array}$ & $\begin{array}{l}\text { Proportion of } \\
\text { ART triplets and } \\
\text { higher-order } \\
\text { infants among all } \\
\text { triplets and } \\
\text { higher-order } \\
\text { infants (\%) }\end{array}$ \\
\hline Alabama & $185(42.5)$ & $2,213(3.7)$ & 8.4 & 169 (38.9) & $2,110(3.5)$ & 8.0 & $16(3.7)$ & $103(0.2)$ & 15.5 \\
\hline Alaska & $41(47.1)$ & $-(-)^{* *}$ & —** & —** (36.8) & $328(2.9)$ & 9.8 & $9(10.3)$ & $-(-)^{* *}$ & —t+ \\
\hline Arizonaศศ & $386(40.1)$ & $2,528(3.0)$ & 15.3 & $356(37.0)$ & $2,444(2.9)$ & 14.6 & $30(3.1)$ & $8(0.1)$ & 35.7 \\
\hline Arkansas & $93(42.9)$ & $1,262(3.2)$ & 7.4 & $-(-)^{* *}$ & $1,223(3.1)$ & —** & $-(-)^{* *}$ & $39(0.1)$ & —** \\
\hline California"ๆ & $2,986(33.8)$ & $15,654(3.2)$ & 19.1 & $2,893(32.7)$ & $15,250(3.1)$ & 19.0 & $93(1.1)$ & $404(0.1)$ & 23.0 \\
\hline Colorado" & $324(30.1)$ & $2,070(3.1)$ & 15.7 & $-(-)^{* *}$ & $2,037(3.1)$ & —** & $-(-)^{* *}$ & $33(0)$ & —** \\
\hline Connecticut & $464(35.7)$ & $1,475(4.1)$ & 31.5 & 440 (33.9) & $1,427(4.0)$ & 30.8 & $24(1.8)$ & $48(0.1)$ & 50.0 \\
\hline Delaware & $48(18.3)$ & $368(3.3)$ & 13.0 & $42(16.0)$ & $353(3.2)$ & 11.9 & $6(2.3)$ & $15(0.1)$ & - $^{\dagger+}$ \\
\hline District of Columbia & $78(21.7)$ & $451(4.7)$ & 17.3 & $78(21.7)$ & $438(4.6)$ & 17.8 & $0(0)$ & $13(0.1)$ & $-{ }^{\dagger+}$ \\
\hline Florida & $1,168(39.4)$ & 7,499 (3.3) & 15.6 & $1,120(37.8)$ & $7,299(3.3)$ & 15.3 & $48(1.6)$ & $200(0.1)$ & 24.0 \\
\hline Georgia & 493 (31.2) & $4,532(3.4)$ & 10.9 & $460(29.1)$ & $4,391(3.3)$ & 10.5 & $33(2.1)$ & $141(0.1)$ & 23.4 \\
\hline Hawaiiๆต & $232(45.8)$ & $520(2.8)$ & 44.6 & $218(43.1)$ & $500(2.7)$ & 43.6 & $14(2.8)$ & $20(0.1)$ & 70.0 \\
\hline Idaho & $142(57.5)$ & $760(3.3)$ & 18.7 & $133(53.8)$ & $738(3.2)$ & 18.0 & $9(3.6)$ & $22(0.1)$ & 40.9 \\
\hline Illinois & $1,505(37.1)$ & $6,160(3.9)$ & 24.4 & $1,451(35.8)$ & $5,999(3.8)$ & 24.2 & $54(1.3)$ & $161(0.1)$ & 33.5 \\
\hline Indiana & $394(46.8)$ & $2,876(3.4)$ & 13.7 & $376(44.7)$ & $2,792(3.3)$ & 13.5 & $18(2.1)$ & $84(0.1)$ & 21.4 \\
\hline lowa & $229(35.4)$ & $1,346(3.4)$ & 17.0 & $224(34.7)$ & $1,307(3.3)$ & 17.1 & $5(0.8)$ & $39(0.1)$ & 12.8 \\
\hline Kansas & $170(42.9)$ & $1,247(3.2)$ & 13.6 & $160(40.4)$ & $1,206(3.1)$ & 13.3 & $10(2.5)$ & $41(0.1)$ & 24.4 \\
\hline Kentucky & $208(43.4)$ & $1,885(3.4)$ & 11.0 & $201(42.0)$ & $1,838(3.3)$ & 10.9 & $7(1.5)$ & $47(0.1)$ & 14.9 \\
\hline Louisiana & $203(40.3)$ & $2,250(3.5)$ & 9.0 & $189(37.5)$ & $2,149(3.3)$ & 8.8 & $14(2.8)$ & $101(0.2)$ & 13.9 \\
\hline Maine & $43(30.7)$ & $388(3.1)$ & 11.1 & $-(-)^{* *}$ & $375(3.0)$ & 一** & $-(-)^{* *}$ & $13(0.1)$ & —**,t十 \\
\hline Maryland & $423(22.4)$ & $2,590(3.5)$ & 16.3 & 405 (21.4) & $2,518(3.4)$ & 16.1 & $18(1.0)$ & $72(0.1)$ & 25.0 \\
\hline Massachusetts & $781(24.0)$ & $2,728(3.8)$ & 28.6 & $766(23.6)$ & $2,671(3.7)$ & 28.7 & $15(0.5)$ & $57(0.1)$ & 26.3 \\
\hline Michigan & $615(41.7)$ & $4,228(3.7)$ & 14.5 & $588(39.9)$ & $4,068(3.6)$ & 14.5 & $27(1.8)$ & $160(0.1)$ & 16.9 \\
\hline Minnesota & $425(38.3)$ & $2,479(3.5)$ & 17.1 & $404(36.4)$ & $2,379(3.4)$ & 17.0 & $21(1.9)$ & $100(0.1)$ & 21.0 \\
\hline Mississippi & $123(47.3)$ & $1,371(3.6)$ & 9.0 & $123(47.3)$ & $1,353(3.5)$ & 9.1 & $0(0)$ & $18(0)$ & —†+ \\
\hline Missouri & $354(39.5)$ & $-(-)^{* *}$ & 12.8 & $330(36.8)$ & $2,677(3.6)$ & 12.3 & $24(2.7)$ & $83(0.1)$ & 28.9 \\
\hline Montana & 50 (37.9) & $-(-)^{* *}$ & —** & 50 (37.9) & $432(3.4)$ & 11.6 & $0(0)$ & $-(-)^{* *}$ & $-^{\dagger+}$ \\
\hline Nebraska & $158(41.5)$ & $1,064(4.0)$ & 14.8 & $-(-)^{* *}$ & $1,018(3.8)$ & —** & $-(-)^{* *}$ & $46(0.2)$ & —** \\
\hline Nevada & $199(37.5)$ & $1,199(3.3)$ & 16.6 & $190(35.8)$ & $1,177(3.2)$ & 16.1 & $9(1.7)$ & $22(0.1)$ & 40.9 \\
\hline New Hampshire & $89(29.1)$ & $460(3.7)$ & 19.3 & $-(-)^{* *}$ & $448(3.6)$ & —** & $-(-)^{* *}$ & $12(0.1)$ & —**,十† \\
\hline New Jersey & $1,137(31.5)$ & $4,253(4.1)$ & 26.7 & $1,112(30.9)$ & $4,138(4.0)$ & 26.9 & $25(0.7)$ & $115(0.1)$ & 21.7 \\
\hline New Mexico & $34(28.6)$ & $626(2.4)$ & 5.4 & $34(28.6)$ & $610(2.4)$ & 5.6 & $0(0)$ & $16(0.1)$ & - $^{+\dagger}$ \\
\hline New York & $2,068(32.1)$ & 8,789 (3.7) & 23.5 & 2,019 (31.4) & $8,500(3.6)$ & 23.8 & $49(0.8)$ & $289(0.1)$ & 17.0 \\
\hline North Carolina & $570(36.4)$ & $4,251(3.5)$ & 13.4 & $552(35.3)$ & $4,120(3.4)$ & 13.4 & $18(1.2)$ & $131(0.1)$ & 13.7 \\
\hline North Dakota & $58(42.0)$ & $-(-)^{* *}$ & —** & $58(42.0)$ & $345(3.0)$ & 16.8 & $0(0)$ & $-(-)^{* *}$ & - \\
\hline Ohio & 735 (42.6) & $5,002(3.6)$ & 14.7 & $686(39.8)$ & $4,790(3.4)$ & 14.3 & $49(2.8)$ & $212(0.2)$ & 23.1 \\
\hline Oklahoma & $192(46.3)$ & $1,710(3.2)$ & 11.2 & $-(-)^{* *}$ & $1,682(3.2)$ & —** & $-(-)^{* *}$ & $28(0.1)$ & —** \\
\hline Oregon & $352(45.4)$ & $1,573(3.4)$ & 22.4 & $331(42.7)$ & $1,534(3.4)$ & 21.6 & $21(2.7)$ & $39(0.1)$ & 53.8 \\
\hline Pennsylvania & $725(31.5)$ & $5,046(3.6)$ & 14.4 & $711(30.9)$ & $4,932(3.5)$ & 14.4 & $14(0.6)$ & $114(0.1)$ & 12.3 \\
\hline Puerto Rico & $56(55.4)$ & $723(2.3)$ & 7.7 & $48(47.5)$ & $702(2.3)$ & 6.8 & $8(7.9)$ & $21(0.1)$ & 38.1 \\
\hline Rhode Island & $94(35.1)$ & $403(3.7)$ & 23.3 & $88(32.8)$ & $382(3.5)$ & 23.0 & $6(2.2)$ & $21(0.2)$ & 28.6 \\
\hline South Carolina & $253(41.4)$ & $2,128(3.7)$ & 11.9 & $238(39.0)$ & $2,085(3.6)$ & 11.4 & $15(2.5)$ & $43(0.1)$ & 34.9 \\
\hline South Dakota & $30(28.8)$ & $390(3.2)$ & 7.7 & $24(23.1)$ & $374(3.0)$ & 6.4 & $6(5.8)$ & $16(0.1)$ & - $^{\dagger+}$ \\
\hline Tennessee & $266(38.3)$ & $2,810(3.4)$ & 9.5 & $254(36.6)$ & $2,710(3.3)$ & 9.4 & $12(1.7)$ & $100(0.1)$ & 12.0 \\
\hline Texas & $2,333(40.4)$ & $13,024(3.2)$ & 17.9 & $2,220(38.4)$ & $12,559(3.1)$ & 17.7 & $113(2.0)$ & $465(0.1)$ & 24.3 \\
\hline Utahๆๆ & $450(47.2)$ & $1,838(3.6)$ & 24.5 & $432(45.3)$ & $1,774(3.5)$ & 24.4 & 18 (1.9) & $64(0.1)$ & 28.1 \\
\hline Vermont & $20(29.0)$ & $-(-)^{* *}$ & —** & $20(29.0)$ & $200(3.4)$ & 10.0 & $0(0)$ & $-(-)^{* *}$ & -†† \\
\hline Virginia & $563(27.4)$ & $3,610(3.5)$ & 15.6 & $551(26.8)$ & $3,498(3.4)$ & 15.8 & $12(0.6)$ & $112(0.1)$ & 10.7 \\
\hline Washington & $410(29.5)$ & $2,883(3.2)$ & 14.2 & $404(29.1)$ & $2,822(3.2)$ & 14.3 & $6(0.4)$ & $61(0.1)$ & 9.8 \\
\hline West Virginia & $61(42.7)$ & $607(3.1)$ & 10.0 & $54(37.8)$ & $591(3.0)$ & 9.1 & $7(4.9)$ & $16(0.1)$ & $-{ }^{+\dagger}$ \\
\hline Wisconsin & $359(42.4)$ & $2,372(3.5)$ & 15.1 & $339(40.0)$ & $2,305(3.4)$ & 14.7 & $20(2.4)$ & $67(0.1)$ & 29.9 \\
\hline Wyoming & 38 (46.9) & $271(3.5)$ & 14.0 & $-(-)^{* *}$ & $259(3.3)$ & —** & $-(-)^{* *}$ & $12(0.2)$ & —**,十† \\
\hline Total & $23,413(35.3)$ & $138,001(3.4)$ & 17.0 & 22,491 (33.9) & $133,857(3.3)$ & 16.8 & $922(1.4)$ & $4,144(0.1)$ & 22.2 \\
\hline
\end{tabular}

Abbreviation: ART = assisted reproductive technology.

* In cases of missing residency data (0.8\%), the patient's residence was assigned as the location in which the ART procedure was performed.

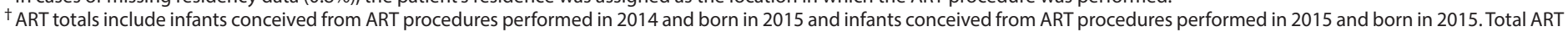
births exclude nonresidents.

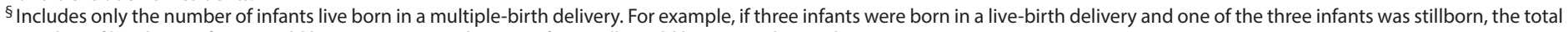
number of live-born infants would be two. However, the two infants still would be counted as triplets.

I U.S. births include nonresidents. Source: Martin JA, Hamilton BE, Osterman MJ, Driscoll AK, Mathews TJ. Births: final data for 2015. Natl Vital Stat Rep 2017;66:1-70.

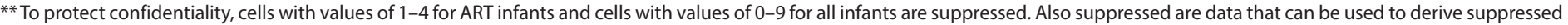
cell values. These values are included in the totals.

${ }^{\dagger \dagger}$ Estimates on the basis of $\mathrm{N}<20$ in the denominator have been suppressed because such rates are considered unstable.

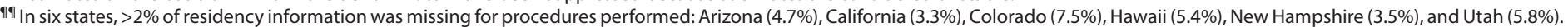
Overall, residency information was missing for 1,468 (0.8\%) procedures performed and $623(1.1 \%)$ live-birth deliveries. 
TABLE 5. Number, percentage, and proportion of infants born with use of assisted reproductive technology, ${ }^{*}$ by low birthweight category and female patient's reporting area of residence ${ }^{\dagger}$ at time of treatment — United States and Puerto Rico, 2015

\begin{tabular}{|c|c|c|c|c|c|c|}
\hline \multirow{3}{*}{$\begin{array}{l}\text { Patient's reporting } \\
\text { area of residence }\end{array}$} & \multicolumn{3}{|c|}{$<2,500 \mathrm{~g}(\mathrm{LBW})$} & \multicolumn{3}{|c|}{$<1,500 \mathrm{~g}(\mathrm{VLBW})$} \\
\hline & \multirow{2}{*}{$\begin{array}{c}\text { ART infants } \\
\text { No. }(\%)\end{array}$} & \multirow{2}{*}{$\begin{array}{c}\text { All infants } \\
\text { No. }(\%)\end{array}$} & \multirow{2}{*}{$\begin{array}{l}\text { Proportion of ART LBW } \\
\text { infants among all LBW } \\
\text { infants (\%) }\end{array}$} & \multirow{2}{*}{$\begin{array}{c}\text { ART infants } \\
\text { No. (\%) }\end{array}$} & \multirow{2}{*}{$\frac{\text { All infants }}{\S}$} & \multirow{2}{*}{$\begin{array}{c}\text { Proportion of ART VLBW } \\
\text { infants among all VLBW } \\
\text { infants (\%) }\end{array}$} \\
\hline & & & & & & \\
\hline Alabama & $151(35.1)$ & $6,218(10.4)$ & 2.4 & $21(4.9)$ & $1,176(2.0)$ & 1.8 \\
\hline Alaska & $24(27.9)$ & $646(5.7)$ & 3.7 & $-(-)^{n}$ & $98(0.9)$ & - \\
\hline Arizona** & $281(29.6)$ & $6,128(7.2)$ & 4.6 & $34(3.6)$ & $961(1.1)$ & 3.5 \\
\hline Arkansas & $56(25.9)$ & $3,564(9.2)$ & 1.6 & $5(2.3)$ & 609 (1.6) & 0.8 \\
\hline California** & $2,113(24.5)$ & $33,666(6.8)$ & 6.3 & $322(3.7)$ & $5,527(1.1)$ & 5.8 \\
\hline Colorado** & $268(25.2)$ & $6,001(9.0)$ & 4.5 & $32(3.0)$ & $761(1.1)$ & 4.2 \\
\hline Connecticut & $342(26.5)$ & $2,836(7.9)$ & 12.1 & $50(3.9)$ & $557(1.6)$ & 9.0 \\
\hline Delaware & 49 (18.8) & $1,036(9.3)$ & 4.7 & $12(4.6)$ & $208(1.9)$ & 5.8 \\
\hline District of Columbia & $60(16.7)$ & $959(10.0)$ & 6.3 & $10(2.8)$ & $206(2.2)$ & 4.9 \\
\hline Florida & $781(26.9)$ & $19,306(8.6)$ & 4.0 & $151(5.2)$ & $3,433(1.5)$ & 4.4 \\
\hline Georgia & $396(25.2)$ & $12,464(9.5)$ & 3.2 & $66(4.2)$ & $2,354(1.8)$ & 2.8 \\
\hline Hawaii** & $163(33.3)$ & $1,531(8.3)$ & 10.6 & $26(5.3)$ & 245 (1.3) & 10.6 \\
\hline Idaho & $93(37.7)$ & $1,501(6.6)$ & 6.2 & $15(6.1)$ & $238(1.0)$ & 6.3 \\
\hline Illinois & $1,030(25.7)$ & $13069(8.3)$ & 7.9 & $180(4.5)$ & 2,319 (1.5) & 7.8 \\
\hline Indiana & 241 (28.9) & $6,725(8.0)$ & 3.6 & $59(7.1)$ & 1,209 (1.4) & 4.9 \\
\hline lowa & $157(24.3)$ & $2,663(6.7)$ & 5.9 & $37(5.7)$ & 486 (1.2) & 7.6 \\
\hline Kansas & $116(29.9)$ & $2,672(6.8)$ & 4.3 & $16(4.1)$ & $476(1.2)$ & 3.4 \\
\hline Kentucky & $122(26.5)$ & $4,846(8.7)$ & 2.5 & $11(2.4)$ & $784(1.4)$ & 1.4 \\
\hline Louisiana & $158(31.3)$ & $6,839(10.6)$ & 2.3 & $34(6.7)$ & $1,261(1.9)$ & 2.7 \\
\hline Maine & $27(20.1)$ & $871(6.9)$ & 3.1 & $-(-)^{9}$ & 154 (1.2) & - \\
\hline Maryland & $386(20.5)$ & $6,297(8.6)$ & 6.1 & $72(3.8)$ & $1,202(1.6)$ & 6.0 \\
\hline Massachusetts & 615 (19.2) & $5,312(7.4)$ & 11.6 & $93(2.9)$ & $851(1.2)$ & 10.9 \\
\hline Michigan & 401 (27.5) & $9,612(8.5)$ & 4.2 & $77(5.3)$ & $1,707(1.5)$ & 4.5 \\
\hline Minnesota & $275(24.9)$ & $4,494(6.4)$ & 6.1 & $42(3.8)$ & 799 (1.1) & 5.3 \\
\hline Mississippi & 81 (31.4) & $4,387(11.4)$ & 1.8 & $19(7.4)$ & $817(2.1)$ & 2.3 \\
\hline Missouri & $237(28.2)$ & $6,248(8.3)$ & 3.8 & $47(5.6)$ & $1,114(1.5)$ & 4.2 \\
\hline Montana & $28(21.2)$ & $878(7.0)$ & 3.2 & $-(-)^{9}$ & $95(0.8)$ & — \\
\hline Nebraska & $104(27.3)$ & $1,893(7.1)$ & 5.5 & $10(2.6)$ & $293(1.1)$ & 3.4 \\
\hline Nevada & $144(28.6)$ & $3,093(8.5)$ & 4.7 & $27(5.4)$ & $478(1.3)$ & 5.6 \\
\hline New Hampshire** & $64(21.1)$ & $845(6.8)$ & 7.6 & $7(2.3)$ & $107(0.9)$ & 6.5 \\
\hline New Jersey & $849(23.7)$ & $8,345(8.1)$ & 10.2 & $139(3.9)$ & $1,468(1.4)$ & 9.5 \\
\hline New Mexico & $34(28.8)$ & $2,244(8.7)$ & 1.5 & $8(6.8)$ & $302(1.2)$ & 2.6 \\
\hline New York & $1,510(24.1)$ & $18,507(7.8)$ & 8.2 & $251(4.0)$ & $3,188(1.3)$ & 7.9 \\
\hline North Carolina & 405 (25.9) & $11,023(9.1)$ & 3.7 & $63(4.0)$ & $2,106(1.7)$ & 3.0 \\
\hline North Dakota & $36(26.5)$ & $700(6.2)$ & 5.1 & $15(11.0)$ & $138(1.2)$ & 10.9 \\
\hline Ohio & $483(28.2)$ & $11,807(8.5)$ & 4.1 & $58(3.4)$ & $2,032(1.5)$ & 2.9 \\
\hline Oklahoma & $133(32.4)$ & $4,172(7.9)$ & 3.2 & $17(4.1)$ & $726(1.4)$ & 2.3 \\
\hline Oregon & $221(28.7)$ & $2,919(6.4)$ & 7.6 & $28(3.6)$ & $453(1.0)$ & 6.2 \\
\hline Pennsylvania & $546(24.1)$ & $11,453(8.1)$ & 4.8 & $93(4.1)$ & $1,997(1.4)$ & 4.7 \\
\hline Puerto Rico & $49(48.5)$ & $3,282(10.5)$ & 1.5 & $13(12.9)$ & $448(1.4)$ & 2.9 \\
\hline Rhode Island & $53(20.0)$ & $833(7.6)$ & 6.4 & $10(3.8)$ & $155(1.4)$ & 6.5 \\
\hline South Carolina & $173(28.6)$ & $5,535(9.5)$ & 3.1 & $32(5.3)$ & $1,029(1.8)$ & 3.1 \\
\hline South Dakota & $24(23.1)$ & $754(6.1)$ & 3.2 & $0(0)$ & $127(1.0)$ & 0 \\
\hline Tennessee & $179(26.1)$ & $7,460(9.1)$ & 2.4 & $35(5.1)$ & $1,318(1.6)$ & 2.7 \\
\hline Texas & $1,690(29.5)$ & $33,275(8.2)$ & 5.1 & $352(6.1)$ & $5,683(1.4)$ & 6.2 \\
\hline Utah ${ }^{* *}$ & 309 (32.6) & $3,561(7.0)$ & 8.7 & $51(5.4)$ & $515(1.0)$ & 9.9 \\
\hline Vermont & $9(13.0)$ & $386(6.5)$ & 2.3 & $0(0)$ & $51(0.9)$ & 0 \\
\hline Virginia & 399 (19.6) & $8,111(7.9)$ & 4.9 & $71(3.5)$ & $1,545(1.5)$ & 4.6 \\
\hline Washington & $280(20.3)$ & $5,730(6.4)$ & 4.9 & $37(2.7)$ & $973(1.1)$ & 3.8 \\
\hline West Virginia & 45 (31.7) & $1,891(9.5)$ & 2.4 & $12(8.5)$ & $284(1.4)$ & 4.2 \\
\hline Wisconsin & $235(28.0)$ & $4,870(7.3)$ & 4.8 & $49(5.8)$ & $868(1.3)$ & 5.6 \\
\hline Wyoming & $25(30.9)$ & 666 (8.6) & 3.8 & $-(-)^{9}$ & $82(1.1)$ & - \\
\hline Total & $16,650(25.5)$ & $324,124(8.1)$ & 5.1 & $2,815(4.3)$ & $56,013(1.4)$ & 5.0 \\
\hline
\end{tabular}

Abbreviations: ART = assisted reproductive technology; LBW = low birthweight; VLBW = very low birthweight.

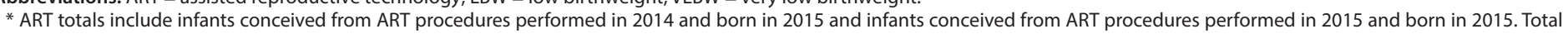
ART infants exclude nonresidents and include only infants with birthweight data available.

$\dagger$ In cases of missing residency data (0.8\%), the patient's residence was assigned as the location in which the ART procedure was performed.

$\S$ U.S. births include nonresidents. Source: Martin JA, Hamilton BE, Osterman MJ, Driscoll AK, Mathews TJ. Births: final data for 2015. Natl Vital Stat Rep 2017;66:1-70.

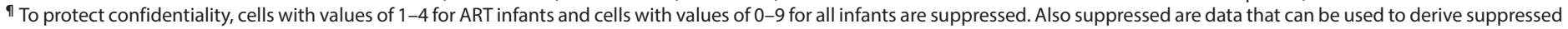
cell values. These values are included in the totals.

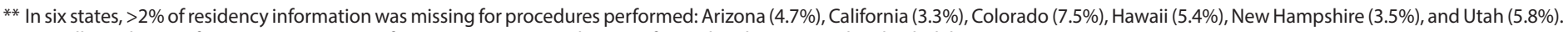
Overall, residency information was missing for 1,468 (0.8\%) procedures performed and $623(1.1 \%)$ live-birth deliveries. 
TABLE 6. Number, percentage, and proportion of infants born with use of assisted reproductive technology, by preterm gestational age category and female patient's reporting area of residence ${ }^{\dagger}$ at time of treatment - United States and Puerto Rico, 2015

\begin{tabular}{|c|c|c|c|c|c|c|}
\hline \multirow[b]{3}{*}{$\begin{array}{l}\text { Patient's reporting } \\
\text { area of residence }\end{array}$} & \multicolumn{3}{|c|}{$<37$ wks (PTB) } & \multicolumn{3}{|c|}{$<32$ wks (VPTB) } \\
\hline & ART infants & All infants ${ }^{\S}$ & \multirow{2}{*}{$\begin{array}{l}\text { Proportion of } \\
\text { ART PTB infants } \\
\text { among all PTB } \\
\text { infants (\%) }\end{array}$} & ART infants & All infants ${ }^{\S}$ & \multirow{2}{*}{$\begin{array}{l}\text { Proportion of ART } \\
\text { VPTB infants } \\
\text { among all VPTB } \\
\text { infants (\%) }\end{array}$} \\
\hline & No. (\%) & No. (\%) & & No. (\%) & No. (\%) & \\
\hline Alabama & $198(45.8)$ & $7,544(12.6)$ & 2.6 & $38(8.8)$ & $1,268(2.1)$ & 3.0 \\
\hline Alaska & $30(34.9)$ & $1,004(8.9)$ & 3.0 & $-(-)^{9}$ & $130(1.2)$ & - \\
\hline Arizona** & $359(37.6)$ & $7,724(9.0)$ & 4.6 & $59(6.2)$ & $1,121(1.3)$ & 5.3 \\
\hline Arkansas & $66(30.6)$ & 4,201 (10.8) & 1.6 & $8(3.7)$ & $683(1.8)$ & 1.2 \\
\hline California** & $2,476(28.3)$ & $41,600(8.5)$ & 6.0 & $401(4.6)$ & $6,386(1.3)$ & 6.3 \\
\hline Colorado** & $333(31.1)$ & $5,770(8.7)$ & 5.8 & $51(4.8)$ & $806(1.2)$ & 6.3 \\
\hline Connecticut & $371(28.6)$ & $3,340(9.3)$ & 11.1 & $65(5.0)$ & $599(1.7)$ & 10.9 \\
\hline Delaware & $65(25.1)$ & $1,093(9.8)$ & 5.9 & $12(4.6)$ & $219(2.0)$ & 5.5 \\
\hline District of Columbia & $75(21.1)$ & $979(10.2)$ & 7.7 & $12(3.4)$ & $199(2.1)$ & 6.0 \\
\hline Florida & $962(32.6)$ & $22,407(10.0)$ & 4.3 & $177(6.0)$ & $3,984(1.8)$ & 4.4 \\
\hline Georgia & $526(33.5)$ & $14,133(10.8)$ & 3.7 & $80(5.1)$ & $2,567(2.0)$ & 3.1 \\
\hline Hawaii** & $189(37.4)$ & $1,861(10.1)$ & 10.2 & $30(5.9)$ & $282(1.5)$ & 10.6 \\
\hline Idaho & $100(41.0)$ & $1,852(8.1)$ & 5.4 & $9(3.7)$ & $255(1.1)$ & 3.5 \\
\hline Illinois & 1,278 (31.7) & $16,048(10.1)$ & 8.0 & $236(5.9)$ & $2,784(1.8)$ & 8.5 \\
\hline Indiana & $318(37.9)$ & $8,061(9.6)$ & 3.9 & $68(8.1)$ & $1,349(1.6)$ & 5.0 \\
\hline lowa & $221(34.2)$ & $3,559(9.0)$ & 6.2 & $41(6.3)$ & $558(1.4)$ & 7.3 \\
\hline Kansas & $140(35.6)$ & $3,426(8.8)$ & 4.1 & $17(4.3)$ & $526(1.3)$ & 3.2 \\
\hline Kentucky & $186(39.0)$ & $6,026(10.8)$ & 3.1 & $21(4.4)$ & 870 (1.6) & 2.4 \\
\hline Louisiana & $223(44.2)$ & $7,964(12.3)$ & 2.8 & $38(7.5)$ & $1,414(2.2)$ & 2.7 \\
\hline Maine & $43(30.7)$ & $1,062(8.4)$ & 4.0 & $8(5.7)$ & $187(1.5)$ & 4.3 \\
\hline Maryland & $458(24.3)$ & $7,380(10.0)$ & 6.2 & $82(4.4)$ & $1,355(1.8)$ & 6.1 \\
\hline Massachusetts & $749(23.2)$ & $6,002(8.4)$ & 12.5 & $119(3.7)$ & 999 (1.4) & 11.9 \\
\hline Michigan & $514(34.9)$ & $11,200(9.9)$ & 4.6 & $92(6.3)$ & $1,963(1.7)$ & 4.7 \\
\hline Minnesota & $336(30.4)$ & $5,906(8.5)$ & 5.7 & $56(5.1)$ & $923(1.3)$ & 6.1 \\
\hline Mississippi & $104(40.0)$ & $4,999(13.0)$ & 2.1 & $23(8.8)$ & $879(2.3)$ & 2.6 \\
\hline Missouri & $321(36.0)$ & $7,504(10.0)$ & 4.3 & $59(6.6)$ & $1,246(1.7)$ & 4.7 \\
\hline Montana & $32(24.2)$ & $1,058(8.4)$ & 3.0 & $-(-)^{9}$ & $123(1.0)$ & — \\
\hline Nebraska & $135(35.4)$ & $2,629(9.9)$ & 5.1 & $11(2.9)$ & $354(1.3)$ & 3.1 \\
\hline Nevada & $163(30.8)$ & 3,604 (9.9) & 4.5 & $24(4.5)$ & $542(1.5)$ & 4.4 \\
\hline New Hampshire** & $67(22.0)$ & 977 (7.9) & 6.9 & $12(3.9)$ & $146(1.2)$ & 8.2 \\
\hline New Jersey & $1,080(30.0)$ & $10,064(9.8)$ & 10.7 & $166(4.6)$ & $1,630(1.6)$ & 10.2 \\
\hline New Mexico & $44(37.0)$ & $2,459(9.5)$ & 1.8 & $10(8.4)$ & $332(1.3)$ & 3.0 \\
\hline New York & $1,663(25.9)$ & $20,531(8.7)$ & 8.1 & $272(4.2)$ & $3,536(1.5)$ & 7.7 \\
\hline North Carolina & $481(30.9)$ & $12,297(10.2)$ & 3.9 & $80(5.1)$ & $2,351(1.9)$ & 3.4 \\
\hline North Dakota & $45(32.8)$ & $950(8.4)$ & 4.7 & $16(11.7)$ & $149(1.3)$ & 10.7 \\
\hline Ohio & $581(33.8)$ & $14,300(10.3)$ & 4.1 & $67(3.9)$ & $2,393(1.7)$ & 2.8 \\
\hline Oklahoma & $174(42.0)$ & $5,485(10.3)$ & 3.2 & $25(6.0)$ & $820(1.5)$ & 3.0 \\
\hline Oregon & $255(33.1)$ & $3,459(7.6)$ & 7.4 & $41(5.3)$ & $521(1.1)$ & 7.9 \\
\hline Pennsylvania & $671(29.3)$ & $13,224(9.4)$ & 5.1 & $99(4.3)$ & $2,257(1.6)$ & 4.4 \\
\hline Puerto Rico & 45 (44.6) & $4,663(15.0)$ & 1.0 & $15(14.9)$ & $698(2.2)$ & 2.1 \\
\hline Rhode Island & $68(25.4)$ & $945(8.6)$ & 7.2 & $11(4.1)$ & $152(1.4)$ & 7.2 \\
\hline South Carolina & $210(34.7)$ & $6,429(11.1)$ & 3.3 & $37(6.1)$ & $1,162(2.0)$ & 3.2 \\
\hline South Dakota & $35(34.3)$ & $1,045(8.5)$ & 3.3 & $-(-)^{9}$ & $131(1.1)$ & -9 \\
\hline Tennessee & $252(36.3)$ & $8,959(11.0)$ & 2.8 & $43(6.2)$ & $1,443(1.8)$ & 3.0 \\
\hline Texas & $2,234(38.9)$ & $41,019(10.2)$ & 5.4 & $414(7.2)$ & $6,470(1.6)$ & 6.4 \\
\hline Utah** & $376(39.5)$ & $4,722(9.3)$ & 8.0 & $70(7.4)$ & $652(1.3)$ & 10.7 \\
\hline Vermont & $8(11.6)$ & $429(7.3)$ & 1.9 & $0(0)$ & $70(1.2)$ & 0 \\
\hline Virginia & $550(26.8)$ & $9,549(9.2)$ & 5.8 & $90(4.4)$ & $1,715(1.7)$ & 5.2 \\
\hline Washington & $363(26.2)$ & $7,216(8.1)$ & 5.0 & $60(4.3)$ & $1,155(1.3)$ & 5.2 \\
\hline West Virginia & $63(44.4)$ & $2,223(11.2)$ & 2.8 & $14(9.9)$ & $326(1.6)$ & 4.3 \\
\hline Wisconsin & $300(35.5)$ & $6,271(9.4)$ & 4.8 & $58(6.9)$ & $1,001(1.5)$ & 5.8 \\
\hline Wyoming & $29(35.8)$ & 762 (9.8) & 3.8 & $-(-)^{9}$ & $82(1.1)$ & - \\
\hline Total & $20,565(31.2)$ & $3,87,914(9.7)$ & 5.3 & $3,447(5.2)$ & $63,763(1.6)$ & 5.4 \\
\hline
\end{tabular}

Abbreviations: ART = assisted reproductive technology; PTB = preterm birth; VPTB = very preterm birth.

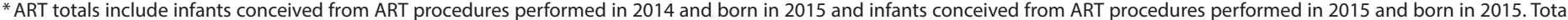
ART births exclude nonresidents and include only infants with gestational age data available.

${ }^{\dagger}$ In cases of missing residency data $(0.8 \%)$, the patient's residence was assigned as the location in which the ART procedure was performed.

$\S$ U.S. births include nonresidents. Source: Martin JA, Hamilton BE, Osterman MJ, Driscoll AK, Mathews TJ. Births: final data for 2015. Natl Vital Stat Rep 2017;66:1-70.

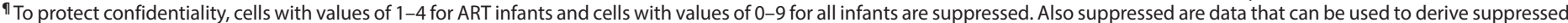
cell values. These values are included in the totals.

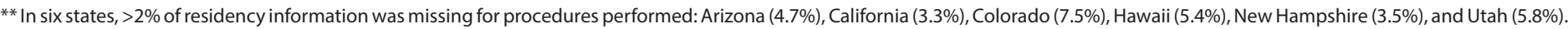
Overall, residency information was missing for 1,468 (0.8\%) procedures performed and $623(1.1 \%)$ live-birth deliveries. 
TABLE 7. Percentages of low birthweight infants $(<2,500 \mathrm{~g})$ among infants born with assisted reproductive technology* and all U.S. infants, by plurality and female patient's reporting area of residence ${ }^{\dagger}$ at time of treatment — United States and Puerto Rico, 2015

\begin{tabular}{|c|c|c|c|c|c|c|}
\hline $\begin{array}{l}\text { Patient's reporting area of } \\
\text { residence }\end{array}$ & $\begin{array}{l}\text { ART singleton } \\
\text { infants (\%) }\end{array}$ & $\begin{array}{l}\text { All singleton } \\
\text { infants }{ }^{\S}(\%)\end{array}$ & $\begin{array}{l}\text { ART twin } \\
\text { infants }(\%)\end{array}$ & $\begin{array}{c}\text { All twin } \\
\text { infants } \\
\text { (\%) }\end{array}$ & $\begin{array}{c}\text { ART triplets and } \\
\text { higher-order infants }{ }^{\mathbb{q}}(\%)\end{array}$ & $\begin{array}{c}\text { All triplets and } \\
\text { higher-order infants }{ }^{\S}(\%)\end{array}$ \\
\hline Alabama & 10.1 & 8.3 & 66.5 & 63.8 & - ${ }^{* *}$ & 96.1 \\
\hline Alaska & - & 4.6 & 40.6 & 40.5 & 一** & —*, †† \\
\hline Arizonaๆๆ & 9.1 & 5.7 & 58.3 & 52.8 & 96.2 & 96.4 \\
\hline Arkansas & 5.7 & 7.4 & 51.1 & 61.3 & —**, †† & 100.0 \\
\hline California१ต & 8.1 & 5.3 & 55.7 & 53.3 & 93.5 & 93.8 \\
\hline Colorado"१ & 9.4 & 7.3 & 61.5 & 63.3 & —**,十† & 93.9 \\
\hline Connecticut & 9.1 & 5.9 & 55.6 & 54.2 & 95.8 & 97.9 \\
\hline Delaware & 8.9 & 7.6 & 57.1 & 52.7 & —**,†† & —** \\
\hline District of Columbia & 6.0 & 7.7 & 55.1 & 55.5 & —§§ & —** \\
\hline Florida & 9.3 & 6.9 & 52.2 & 57.2 & 100.0 & 96.5 \\
\hline Georgia" & 8.8 & 7.6 & 58.8 & 60.2 & 100.0 & 95.7 \\
\hline Hawaiiๆๆ & 13.3 & 6.9 & 55.8 & 53.2 & - ** & 100.0 \\
\hline Idaho & 10.5 & 5.0 & 54.9 & 50.1 & 一** & 100.0 \\
\hline Illinois & 8.1 & 6.4 & 54.2 & 53.8 & 94.4 & 91.9 \\
\hline Indiana & 7.0 & 6.3 & 51.6 & 54.3 & —** & 97.6 \\
\hline lowa & 9.4 & 5.0 & 50.4 & 54.8 & 一** & 97.4 \\
\hline Kansas & 8.6 & 5.3 & 56.3 & 51.2 & - ${ }^{* *}$ & 92.7 \\
\hline Kentucky & 9.1 & 7.0 & 49.2 & 55.3 & —**,t† & 100.0 \\
\hline Louisiana & 8.6 & 8.6 & 62.4 & 64.2 & —** & 100.0 \\
\hline Maine & 6.5 & 5.4 & 50.0 & 49.9 & —**,t† & —** \\
\hline Maryland & 9.1 & 6.8 & 58.1 & 55.0 & - ** & 100.0 \\
\hline Massachusetts & 7.9 & 5.6 & 55.0 & 53.1 & - ** & 91.2 \\
\hline Michigan & 9.7 & 6.6 & 51.6 & 54.6 & 79.2 & 88.8 \\
\hline Minnesota & 7.9 & 4.8 & 50.5 & 48.7 & 95.2 & 88.0 \\
\hline Mississippi & 9.5 & 9.4 & 56.2 & 64.0 & —§§ & —** \\
\hline Missouri & 8.8 & 6.4 & 54.9 & 57.3 & 100.0 & 96.4 \\
\hline Montana & 8.5 & 5.4 & 42.0 & 50.5 & _§§ & —**,十† \\
\hline Nebraska & 9.4 & 5.1 & 52.9 & 54.1 & —**,t† & 87.0 \\
\hline Nevada & 11.4 & 6.8 & 55.6 & 56.5 & 一** & 81.8 \\
\hline New Hampshire ๆ & 7.4 & 5.2 & 53.6 & 45.5 & $* *,+\dagger$ & —** \\
\hline New Jersey & 9.4 & 6.1 & 54.0 & 52.9 & 100.0 & 93.0 \\
\hline New Mexico & 15.5 & 7.3 & 61.8 & 62.3 & _§§ & -** \\
\hline New York & 9.1 & 6.0 & 54.5 & 54.2 & 98.0 & 96.9 \\
\hline North Carolina & 9.9 & 7.4 & 52.5 & 54.6 & —** & 96.9 \\
\hline North Dakota & 7.5 & 4.7 & 53.6 & 50.1 & —§§ & —**,†† \\
\hline Ohio & 8.7 & 6.7 & 51.5 & 54.5 & 95.7 & 92.0 \\
\hline Oklahoma & 8.1 & 6.3 & 59.9 & 55.1 & —**,†† & 100.0 \\
\hline Oregon & 8.3 & 4.9 & 50.5 & 47.5 & 100.0 & 100.0 \\
\hline Pennsylvania & 8.9 & 6.4 & 57.0 & 53.2 & —** & 89.5 \\
\hline Puerto Rico & 22.2 & 9.2 & 70.8 & 66.1 & - ${ }^{* *}$ & 76.2 \\
\hline Rhode Island & 5.2 & 5.8 & 45.3 & 50.5 & - ** & 95.2 \\
\hline South Carolina & 6.0 & 7.7 & 57.6 & 57.6 & —** & 97.7 \\
\hline South Dakota & 10.8 & 4.7 & 45.8 & 44.9 & —** & —** \\
\hline Tennessee & 8.3 & 7.3 & 53.1 & 58.3 & - ** & 98.0 \\
\hline Texas & 9.3 & 6.5 & 57.3 & 58.1 & 95.6 & 96.8 \\
\hline Utah ๆา & 9.6 & 5.2 & 57.2 & 54.2 & —** & 95.3 \\
\hline Vermont & $-{ }^{+\dagger}$ & 4.9 & 40.0 & 49.0 & —§§ & - $* *,+\dagger$ \\
\hline Virginia & 7.4 & 6.1 & 51.0 & 54.1 & 一** & 92.9 \\
\hline Washington & 7.4 & 5.0 & 50.8 & 49.4 & —** & 96.7 \\
\hline West Virginia & 8.6 & 7.9 & 57.4 & 60.2 & - ** & —** \\
\hline Wisconsin & 7.0 & 5.6 & 54.0 & 52.0 & 100.0 & 95.5 \\
\hline Wyoming & 11.6 & 6.6 & 48.6 & 57.5 & —**,t† & 一** \\
\hline Total & 8.7 & 6.4 & 54.8 & 55.2 & 95.9 & 95.0 \\
\hline
\end{tabular}

Abbreviation: ART = assisted reproductive technology.

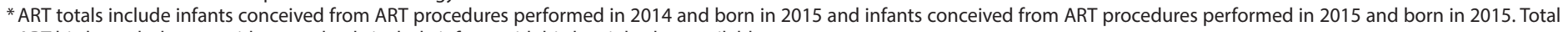
ART births exclude nonresidents and only include infants with birthweight data available.

${ }^{\dagger}$ In cases of missing residency data (0.8\%), the patient's residence was assigned as the location in which the ART procedure was performed.

§ U.S. births include nonresidents. Source: Martin JA, Hamilton BE, Osterman MJ, Driscoll AK, Mathews TJ. Births: final data for 2015. NatI Vital Stat Rep 2017;66:1-70.

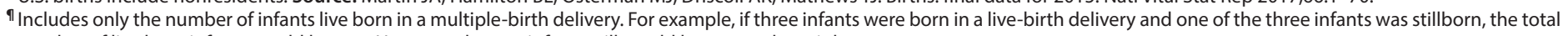
number of live born infants would be two. However, the two infants still would be counted as triplets.

** Estimates on the basis of $\mathrm{N}<20$ in the denominator have been suppressed because such rates are considered unstable.

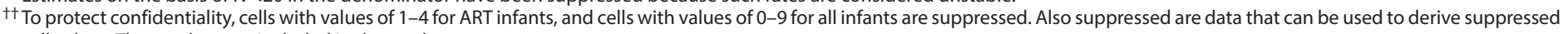
cell values. These values are included in the totals.

$\S \S$ Estimates not calculated because $\mathrm{N}=0$ for the denominator.

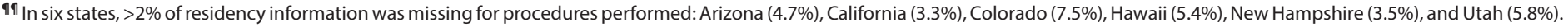
Overall, residency information was missing for 1,468 (0.8\%) procedures performed and $623(1.1 \%)$ live-birth deliveries. 
TABLE 8. Percentages of preterm (<37 weeks) infants among infants born with use of assisted reproductive technology* and all U.S. infants, by plurality and female patient's reporting area of residence ${ }^{\dagger}$ at time of treatment - United States and Puerto Rico, 2015

\begin{tabular}{|c|c|c|c|c|c|c|}
\hline $\begin{array}{l}\text { Patient's reporting area of } \\
\text { residence }\end{array}$ & $\begin{array}{l}\text { ART singleton } \\
\text { infants (\%) }\end{array}$ & $\begin{array}{l}\text { All singleton } \\
\text { infants } \S(\%)\end{array}$ & $\begin{array}{l}\text { ART twin } \\
\text { infants }^{\mathscr{I}}(\%)\end{array}$ & $\begin{array}{c}\text { All twin } \\
\text { infants }^{\S}(\%)\end{array}$ & $\begin{array}{c}\text { ART triplets and } \\
\text { higher-order infants }{ }^{\mathbb{}}(\%)\end{array}$ & $\begin{array}{c}\text { All triplets and } \\
\text { higher-order infants }{ }^{\S}(\%)\end{array}$ \\
\hline Alabama & 17.3 & 9.6 & 83.2 & 66.4 & -** & 97.1 \\
\hline Alaska & 11.1 & 7.7 & 50.0 & 47.0 & - ** & —**,十† \\
\hline Arizona & 14.2 & 7.5 & 70.1 & 58.6 & 100.0 & 98.8 \\
\hline Arkansas & 7.3 & 8.9 & 60.0 & 66.1 & —**,†† & 100.0 \\
\hline Californiaๆๆ & 12.0 & 6.9 & 59.3 & 55.1 & 87.1 & 99.0 \\
\hline Colorado & 14.0 & 7.0 & 70.1 & 59.2 & —**,十† & 100.0 \\
\hline Connecticut & 12.9 & 7.3 & 54.5 & 54.6 & 100.0 & 100.0 \\
\hline Delaware & 14.6 & 8.1 & 70.0 & 58.6 & —** & —** \\
\hline District Of Columbia & 9.0 & 8.0 & 64.1 & 53.4 & —§§ & - ** \\
\hline Florida & 14.5 & 8.2 & 58.8 & 60.1 & 93.8 & 99.0 \\
\hline Georgia & 14.7 & 8.9 & 73.3 & 62.1 & 100.0 & 97.9 \\
\hline Hawaiiๆๆ & 12.1 & 8.5 & 65.1 & 60.4 & —** & 100.0 \\
\hline Idaho & 13.3 & 6.4 & 60.2 & 58.0 & - ** & 100.0 \\
\hline Illinois & 13.7 & 8.1 & 60.9 & 59.9 & 100.0 & 98.8 \\
\hline Indiana & 11.9 & 7.8 & 65.9 & 58.5 & —** & 100.0 \\
\hline lowa & 14.4 & 7.0 & 69.6 & 64.0 & - ** & 97.4 \\
\hline Kansas & 9.9 & 7.1 & 67.5 & 56.1 & - ** & 100.0 \\
\hline Kentucky & 15.9 & 8.9 & 68.3 & 63.0 & - ** & 100.0 \\
\hline Louisiana & 17.3 & 10.2 & 83.1 & 70.5 & - ** & 98.0 \\
\hline Maine & 14.4 & 6.8 & 66.7 & 56.8 & —**,十† & —** \\
\hline Maryland & 12.9 & 8.2 & 62.2 & 59.0 & - ${ }^{* *}$ & 100.0 \\
\hline Massachusetts & 11.5 & 6.5 & 59.5 & 55.4 & - ** & 100.0 \\
\hline Michigan & 14.4 & 7.9 & 61.9 & 59.6 & 100.0 & 96.3 \\
\hline Minnesota & 10.4 & 6.8 & 60.7 & 52.8 & 100.0 & 98.0 \\
\hline Mississippi & 16.8 & 11.0 & 65.9 & 67.8 & —§§ & —** \\
\hline Missouri & 16.0 & 7.9 & 63.9 & 64.5 & 100.0 & 100.0 \\
\hline Montana & 9.8 & 6.7 & 48.0 & 56.5 & — §§ & —**,†† \\
\hline Nebraska & 15.7 & 7.5 & 62.6 & 63.7 & —**,†† & 93.5 \\
\hline Nevada & 13.9 & 8.2 & 56.8 & 59.3 & - ${ }^{* *}$ & 90.9 \\
\hline New Hampshire ๆๆ & 8.3 & 6.2 & 53.5 & 49.6 & —**,十† & - ** \\
\hline New Jersey & 15.4 & 7.7 & 60.9 & 56.5 & 100.0 & 99.1 \\
\hline New Mexico & 18.8 & 8.2 & 82.4 & 63.6 & — $\S$ & -** \\
\hline New York & 12.1 & 6.9 & 54.0 & 53.9 & 93.9 & 99.3 \\
\hline North Carolina & 13.7 & 8.4 & 60.0 & 57.1 & —** & 95.4 \\
\hline North Dakota & 6.3 & 6.9 & 69.0 & 55.7 & —§§ & —**,十† \\
\hline Ohio & 11.4 & 8.3 & 61.2 & 61.1 & 100.0 & 98.1 \\
\hline Oklahoma & 18.9 & 8.6 & 68.3 & 61.9 & —**,†† & 100.0 \\
\hline Oregon & 11.2 & 6.0 & 56.8 & 50.1 & 100.0 & 100.0 \\
\hline Pennsylvania & 14.1 & 7.5 & 61.7 & 58.7 & —** & 98.2 \\
\hline Puerto Rico & 15.6 & 13.8 & 62.5 & 66.1 & - ** & 90.5 \\
\hline Rhode Island & 10.3 & 6.9 & 50.0 & 51.6 & - ** & 100.0 \\
\hline South Carolina & 12.1 & 9.1 & 64.4 & 60.8 & - ** & 100.0 \\
\hline South Dakota & 20.3 & 6.8 & 63.6 & 56.4 & - ** & —** \\
\hline Tennessee & 15.0 & 9.1 & 69.3 & 62.4 & - ** & 100.0 \\
\hline Texas & 16.1 & 8.4 & 71.5 & 62.3 & 97.3 & 98.7 \\
\hline Utahกา & 15.1 & 7.3 & 65.3 & 61.6 & -** & 100.0 \\
\hline Vermont & - ${ }^{\dagger+}$ & 5.5 & 30.0 & 47.5 & —§§ & —**,†† \\
\hline Virginia & 12.9 & 7.4 & 62.8 & 57.5 & 一** & 95.5 \\
\hline Washington & 12.0 & 6.5 & 59.4 & 54.9 & - ** & 100.0 \\
\hline West Virginia & 19.8 & 9.3 & 74.1 & 70.4 & - ** & —** \\
\hline Wisconsin & 13.8 & 7.6 & 62.8 & 56.9 & 100.0 & 100.0 \\
\hline Wyoming & 16.3 & 7.8 & 54.3 & 62.5 & —**,十 & —** \\
\hline Total & 13.4 & 7.9 & 62.4 & 59.0 & 97.7 & 98.6 \\
\hline
\end{tabular}

Abbreviation: ART = assisted reproductive technology.

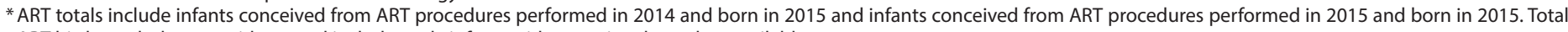
ART births exclude nonresidents and includes only infants with gestational age data available.

$\dagger$ In cases of missing residency data $(0.8 \%)$, the patient's residence was assigned as the location in which the ART procedure was performed.

§ U.S. births include nonresidents. Source: Martin JA, Hamilton BE, Osterman MJ, Driscoll AK, Mathews TJ. Births: final data for 2015. Natl Vital Stat Rep 2017;66:1-70.

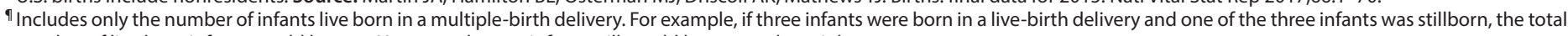
number of live born infants would be two. However, the two infants still would be counted as triplets.

** Estimates on the basis of $\mathrm{N}<20$ in the denominator have been suppressed because such rates are considered unstable.

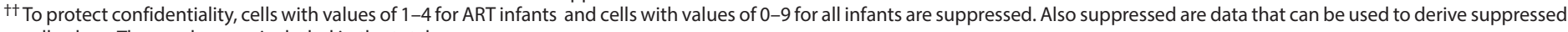
cell values. These values are included in the totals.

$\S \S$ Estimates not calculated because $\mathrm{N}=0$ for the denominator.

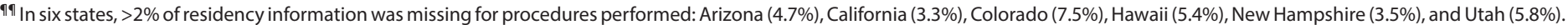
Overall, residency information was missing for 1,468 (0.8\%) procedures performed and $623(1.1 \%)$ live-birth deliveries. 



The Morbidity and Mortality Weekly Report (MMWR) Series is prepared by the Centers for Disease Control and Prevention (CDC) and is available free of charge in electronic format. To receive an electronic copy each week, visit $M M W R$ 's free subscription page at https://www.cdc.gov/mmwr $/ \mathrm{mmwrsubscribe.html}$. Paper copy subscriptions are available through the Superintendent of Documents, U.S. Government Printing Office, Washington, DC 20402; telephone 202-512-1800

Readers who have difficulty accessing this PDF file may access the HTML file at https://www.cdc.gov/mmwr/volumes/67/ss/ss6703a1.htm?s_ cid=ss6703a1_w. Address all inquiries about the $M M W R$ Series, including material to be considered for publication, to Executive Editor, $M M W R$ Series, Mailstop E-90, CDC, 1600 Clifton Rd., N.E., Atlanta, GA 30329-4027 or to mmwrq@cdc.gov.

All material in the MMWR Series is in the public domain and may be used and reprinted without permission; citation as to source, however, is appreciated.

Use of trade names and commercial sources is for identification only and does not imply endorsement by the U.S. Department of Health and Human Services.

References to non-CDC sites on the Internet are provided as a service to $M M W R$ readers and do not constitute or imply endorsement of these organizations or their programs by CDC or the U.S. Department of Health and Human Services. CDC is not responsible for the content of these sites. URL addresses listed in $M M W R$ were current as of the date of publication.

ISSN: 1546-0738 (Print) 